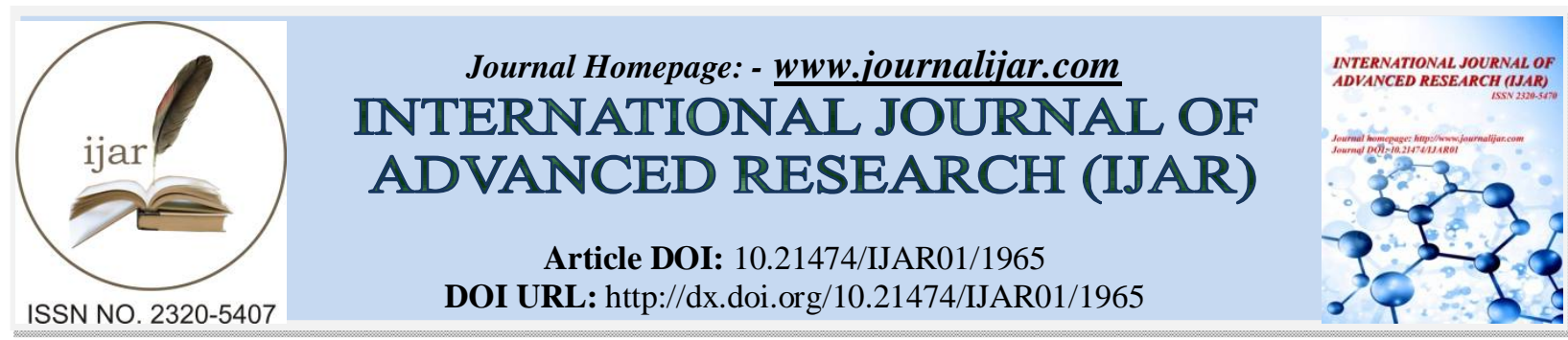

RESEARCH ARTICLE

\title{
OPTIMAL DESIGN OF SYMMETRICAL BARRAGES/REGULATORS USING SHUFFLED COMPLEX EVOLUTION ALGORITHM.
}

\section{"Bastawrous I (MSc) $)^{1}$, Awad H (PhD) $)^{2}$ and Younan N (PhD $)^{3}$.}

1. Civil Engineer, Behera Company, Ministry of Agriculture and Land Reclamation, Egypt.

2. Associate Doctor, Irrigation Engineering and Hydraulics Department, Faculty of Engineering, Alexandria University, Alexandria, Egypt.

3. Professor, Irrigation Engineering and Hydraulics Department, Faculty of Engineering, Alexandria University, Alexandria, Egypt.

\section{Manuscript Info}

Manuscript History

Received: 20 October 2016

Final Accepted: 25 October 2016

Published: October 2016

\section{Abstract}

Background: On the river Nile and its branches, there are more than 360 barrages/regulators, built from nineteenth century to control water discharges used for irrigation, industry and human needs. Barrages/Regulators, generally, consist of the main following parts: intermediate supports, edge supports, upstream and downstream wing walls, the bridge located above the regulator and the floor under the structure with its sheet piles and cut-offs. There is, however, no procedure to fix the basic barrage/regulator parameters; dimensions, material of its elements, types of bridge and hydraulic parameters in a cost-effective manner. Determination of these parameters is not dependant on any standard code; it depends on the designer's decision.

Aim: We aimed at presenting software for the optimal hydraulic and structural design of barrages/regulators based mainly on surface flow and how to reach the most cost-effective technical design. We also aimed at deducing an empirical formula to calculate the barrage elements' cost.

Materials and Methods: Our study has been illustrated using Shuffled Complex Evolution algorithm, developed at the University of Arizona (SCE-UA), as an optimization technique, in which the objective function is the construction cost and the parameters are dimensions, material types, bridge types and hydraulic parameters.

The applicability of this approach has been illustrated using seven existing regulators indicating its suitability to evolve a cost-effective design.

Results: The reductions of construction costs have been recorded for the selected seven examples and founded to be between $11 \%$ and $64 \%$ with an average value of $31 \%$. The software illustrates that the slab type is more optimal than arch or beam type for the bridge, plain concrete for abutments and piers is more optimal than reinforced concrete; combining reinforced and plain concrete for the floor is more optimal than either one alone.

Corresponding Author:- Irini Mahfouz Shenouda Bastawrous

Address:- 1 El-Aalam Street, El-Sayeda Fatma -Bwalino -MoharamBey, Alexandria, Egypt. 
Conclusion: The software demonstrates the pronounced performance of the developed tool; this program can help decision-makers to know the optimal hydraulic and structural design in addition to the optimal cost of the barrages.

Copy Right, IJAR, 2016,. All rights reserved.

\section{Introduction:-}

The barrage/regulator designer must pass two stages to finish the design to the fullest; these two stages are (i) hydraulic design which based on surface flow to determine number of vents, span of vents, floor level and on subsurface flow to determine floor and cut-off lengths and (ii) structural design which focus on structural element material and dimensions.

Firstly, Hydraulic formula used for regulators is similar to a bridge crossing canal or a river (Leliavsky 1957). The formula which is often used in calculating the discharge under such a bridge is

$$
Q=\frac{2}{3} C L_{e} \sqrt{2 g}\left[\left(h+h_{a}\right)^{3 / 2}-h_{a}{ }^{3 / 2}\right]+C L_{e} H \sqrt{2 g\left(h+h_{a}\right)}
$$

Where $h$ is the heading up, i.e. the difference between upstream and downstream water levels;

$h_{a}$ is the head of approach $=\frac{v_{a}^{2}}{2 g}$;

where $v_{a}$ represent the velocity of approach $=\frac{Q}{a}$,

$a$ being the sectional area of the canal upstream the regulator;

$\mathrm{C}$ is the coefficient of discharge,

$\mathrm{H}$ is the downstream water depth,

$L_{e}$ is effective width of regulator,

$g=$ gravitational acceleration, and

$\mathrm{Q}$ is the total discharge of water flowing through the regulator.

This formula has been simplified and becomes

$$
Q=C L_{e} H \sqrt{2 g\left(h+h_{a}\right)}
$$

Then infer the following equation:

$$
h=\frac{1}{c^{2}} \frac{v_{a}^{2}}{2 g}\left[\left(\frac{a}{A}\right)^{2}-1\right]
$$

Where $\mathrm{A}$ is effective water area of regulator.

Formula(2.a) is the main formula in Egypt (ECP 2001).

$$
\begin{aligned}
& C=0.72 \text {. } \quad \text {. } \quad \text { if the span of the opening } \leq 2.00 \mathrm{~m} \\
& C=0.82 \text {. . . . if } 2.00 \mathrm{~m}<\text { the span of the opening } \leq 4.00 \mathrm{~m} \\
& C=0.92 \text {. . . . if the span of the opening }>4.00 \mathrm{~m}
\end{aligned}
$$

Note that formula(2.a) has similar forms with different value of coefficient C (Leliavsky 1957).

The main formula used in India (IS6531:1994) is:

$$
\mathrm{Q}=\mathrm{C}_{\mathrm{d}} \mathrm{L} \mathrm{H}_{\mathrm{e}}^{3 / 2} \text {. }
$$

Where the coefficient $\mathrm{C}_{d}$ is not constant but depends on many factors and $\mathrm{H}_{\mathrm{e}}$ is the required head over crest.

There is another equation has been deduced (Leliavsky 1957, ECP 2001):

$\mathrm{h}=\alpha \beta \frac{\mathrm{v}^{2}}{2 g}$

where $\alpha$ and $\beta$ are coefficients depends on the proportion between canal, regulator cross-sectional areas and on pier shape.

On the other hands, hydraulic design based on subsurface flow, there are three famous theories used to determine length of floor and cut-offs to resist scour, uplift pressure and exit gradient: (i)Bligh theory, formula(5), (6), (ii)Lane theory, formula (7) which are used in Egypt (ECP 2001) and (iii) khosla theory (Khosla 1932, Khosla, Bose et al. 1936) which is used in India (IS6966-1:1989).

$L_{s}=0.6 C_{B} \sqrt{h_{\max }}$

$\mathrm{L}=C_{B} \cdot h_{\max }$

$$
\mathrm{L}=\mathrm{C}_{L} \cdot h_{\max }
$$


Secondly, the structural design; (Leliavsky 1957) divided the regulators to four types:

(i) Masonry and plain concrete regulators of moderate size, regulation by timber, which the determination of elements dimensions, depends on empirical formulas; the bridge is arch and the maximum span equal 3.00 meter.

(ii) Mixed type including both heavy and light materials, the difference between this type and the previous one is the type of bridge and material of floor. Which the floor and bridge constructed from RC, bridge is slab type and beam type.

(iii) Purely reinforced concrete design, which all elements of the regulator are constructed from RC, this ideology followed the American standard design.

(iv) Regulators and barrages fitted with steal gates, which focused on the stability of piers against water pressure loaded on the gates.

According to (ECP 2001): there are no fixed conditions to help the designer make his decision of choosing materials or determining bridge type or even to decide the numbers of vents, and despite of recommends the use of plain concrete and reinforced concrete for the floor, it does not mention using reinforced concrete for abutments, wing walls and piers; it recommends to use brick and plain concrete for them; It also treats with the floor as a rigid footing.

According to Indian Standard (IS11130:1984): For piers and abutments design the (IS) recommends for using reinforced concrete but for raft design, there are two types of raft foundation: (1) gravity type which resists the uplift pressure with its weight only and it made from PC, (2) RC type which resists the uplift pressure with its weight and all loaded weight come from piers and abutment, The design of the RC raft for spans up to $6.00 \mathrm{~m}$ may generally be done same as the theory of beams on elastic foundation while the floor shall be designed as a finite beam resting on elastic foundation and subjected to concentrated loads and moments at the pier and abutment points for spans above $6.00 \mathrm{~m}$. The raft, piers and abutment could be designed as reinforced concrete. It is important to take seismic load and wind load into consideration during pier design.

An optimization model has been formulated to minimize the barrage cost using Khosla's theory (Garg, Bhagat et al. 2002). A genetic algorithm (GA) based on embedded simulation optimization approach to design barrages with minimum cost depending on the depth of sheet piles or cut-offs and the length and thickness of floor in a costeffective manner was studied by (Singh 2011) then he illustrates the effect of seepage head on the choosing of optimal sheet pile depth (Singh 2011). After that (Garg, Chawre et al. 2014)study the impact of heterogeneous and anisotropic soils on the uplift pressure.

In this paper, shuffled complex evolution algorithm, developed at the University of Arizona (SCE-UA) has been used as an optimization technique. It was originally developed by (Duan, Sorooshian et al. 1992). This algorithm is reported to be an efficient global optimization method that can be used to handle non-linear problems with highparameter dimensionality (Duan, Sorooshian et al. 1992, Duan, Gupta et al. 1993, Duan, Sorooshian et al. 1994, Cooper, Nguyen et al. 1997, Kuczera 1997, Franchini, Galeati et al. 1998, Thyer, Kuczera et al. 1999, Wu, Zhu et al. 1999, Muttil and Liong 2004, Wu and Zhu 2006, Le Ngo, Madsen et al. 2007, Jiang and Gong 2012, Jeon, Park et al. 2014).

\section{MATERIALS AND METHODS:-}

\section{A. DESIGN OF SYMMETRICAL REGULATORS}

The Ministry of Water Resources and Irrigation (MWRI) of Egypt decided to carry out a feasibility study to investigate the present structural and operational conditions of most regulators and barrages in Egypt; More than one hundred structures have been inspected and presented in individual reports, these reports include photos, original drawings, hydraulic and structure information about the regulators such as types of materials used for constructing piers, abutments and floors which is brick or plain concrete or reinforced concrete, types of bridge which is arch or slab or beam type, number of vents, span of vents, levels at the top and bottom of regulator elements, levels of canal cross section such as levels of upstream and downstream water levels and discharge that the regulator passes are available; therefore, lots of constructed information have been known; there are eighty three of them are symmetric (without lock) and seventeen are not symmetric (with lock). This study concerns the symmetric regulators, i.e. for the eighty three, seven structures have been considered in this research, i.e. are to be evaluated (Photo 1), firstly the volumes of regulators elements have been calculated, secondly, determinate the cost of bridge, piers, abutment, and floor. 
In every barrage, there are many types of materials and hydraulic parameters which can be changed to make the optimization design in the manner of cost. So our presented program respects the Egyptian code and then is connected with SCE-UA algorithm to optimize every regulator.

The proposed optimization program is presented in Figure 1, this program treats the results as a global optimization problem where the cost functions to be minimized is defined as the differences in inspected and computed dimensions and materials.

The optimal solution is searched in the multi-modal solution space by the SCE algorithm as described previously. Thus, for every hydraulic parameter of module solutions in the SCE search scheme, material types of the regulator's element have to be recalled to compute the resulting cost. In this research, the SCE optimization technique is connected with ODR software which designs the whole regulator dealing with parameters as inputs. This reduces the computational time of SCE during the optimization process. Thus, the resulting composed of mixing parts model; ODR-SCE combines the robustness of SCE with the computational efficiency of ODR.

The optimization technique designed by the authors was implemented in MATLAB. The variables to the toolbox are eighteen variables divided into three groups:

Group No.1: $\quad$ six independent variables which are: N,S (Figure 6), $\mathrm{M}_{\mathrm{ab}}, \mathrm{M}_{\mathrm{fl}}, \mathrm{Br}_{\mathrm{type}}$ (Figure 3, Figure 4, Figure 5), DBF;

Group No.2: nine dependant variables/dimension (Figure 6, Figure 7) which are: $E, T_{a t}, T_{a b}, T_{1 P C}, T_{1 R C}$, $\mathrm{T}_{2 \mathrm{PC}}, \mathrm{T}_{2 \mathrm{RC}}, \mathrm{T}_{3 \mathrm{PC}}, \mathrm{T}_{3 \mathrm{RC}}$;

Group No.3: three calculated parameters (Figure 7) which are: $\mathrm{L}_{1}, \mathrm{~L}_{2}, \mathrm{~L}_{3}$.

The choice of the SCE algorithm's parameters is crucial in achieving convergence of solution for the problem under consideration. In this research, the following guidelines proposed by Duan et al. (1992) were used for determining the SCE parameters.

A total of 364E+20 data vectors generated by modeling design equation using the Egyptian code were used for the multi-Model solution designed by the Authors.

\section{B. OPTIMAL DESIGN METHODOLOGY}

The main idea of the methodology is based on minimizing the cost of barrage elements; this cost is a function of:N, $\mathrm{S}$ (Figure 6), $\mathrm{M}_{\mathrm{ab}}, \mathrm{M}_{\mathrm{fl}}, \mathrm{Br}_{\mathrm{type}}$ (Figure 3, Figure 4, and Figure 5), DBF.

This function can be illustrated in the form of the following equations:

$\mathrm{c}\left(\mathrm{N}, \mathrm{S}, \mathrm{DBF}, \mathrm{M}_{\mathrm{ab}}, \mathrm{M}_{\mathrm{fl}}, \mathrm{Br}_{\mathrm{type}}\right)=\mathrm{c}_{1}\left(\mathrm{f}_{1}\right)+\mathrm{c}_{2}\left(\mathrm{f}_{2}\right)+\mathrm{c}_{3}\left(\mathrm{f}_{3}\right)+\mathrm{c}_{4}\left(\mathrm{f}_{4}\right)$

$\mathrm{c}_{1}\left(\mathrm{f}_{1}\right)=\operatorname{Cost}_{\mathrm{Br} .}=\mathrm{Vol}_{\mathrm{Br} .} \times \operatorname{Cost}_{\mathrm{m} 3(\text { arch or slab or beam) }}$

$\mathrm{c}_{2}\left(\mathrm{f}_{2}\right)=\operatorname{Cost}_{\text {Pier }}=\operatorname{Vol}_{\text {Piers. }} \times \operatorname{Cost}_{\mathrm{m} 3 \text { (Brick or PC or RC) }}$

$\mathrm{c}_{3}\left(\mathrm{f}_{3}\right)=\operatorname{Cost}_{\mathrm{Abut}}=\mathrm{Vol}_{\mathrm{Abut}} \times \operatorname{Cost}_{\mathrm{m} 3 \text { (Brick or PC or RC) }}$

$\mathrm{c}_{4}\left(\mathrm{f}_{4}\right)=\mathrm{Cost}_{\text {Floor. }}=\mathrm{Vol}_{\mathrm{fPC}} \times \operatorname{Cos}_{\mathrm{tm} 3 \mathrm{PC}}+\mathrm{Vol}_{\mathrm{flRC}} \times \operatorname{Cost}_{\mathrm{m} 3 \mathrm{RC}}$

Total Cost $=$ Cost $_{\mathrm{Br}}+$ Cost $_{\text {Piers }}+$ Cost $_{\mathrm{Abut}}+\mathrm{Cost}_{\mathrm{Floor}}$

$\mathrm{c}\left(\mathrm{N}, \mathrm{S}, \mathrm{DBF}, \mathrm{M}_{\mathrm{ab}}, \mathrm{M}_{\mathrm{fl}}, \mathrm{Br}_{\mathrm{type}}\right)=$ Cost $_{\mathrm{Br} .}+$ Cost $_{\text {Piers }}+$ Cost $_{\mathrm{Abut}}+$ Cost $_{\text {Floor }}$

$\mathrm{N}^{l}<\mathrm{N}<\mathrm{N}^{u}$

$\mathrm{S}^{l}<\mathrm{S}<\mathrm{S}^{u}$

$\mathrm{M}_{\mathrm{ab}}{ }^{l}<\mathrm{M}_{\mathrm{ab}}<\mathrm{M}_{\mathrm{ab}}{ }^{u}$

$\mathrm{M}_{\mathrm{fl}}{ }^{l}<\mathrm{M}_{\mathrm{fl}}<\mathrm{M}_{\mathrm{fl}}{ }^{u}$

$\mathrm{Br}_{\text {type }}{ }^{l}<\mathrm{Br}_{\text {type }}<\mathrm{Br}_{\text {type }}{ }^{u}$

$\mathrm{DBF}^{l}<\mathrm{DBF}<\mathrm{DBF}^{u}$

Where $\mathrm{c}\left(\mathrm{N}, \mathrm{S}, \mathrm{M}_{\mathrm{ab}}, \mathrm{M}_{\mathrm{fl}}, \mathrm{Br}_{\mathrm{typ}}, \mathrm{DBF}\right)$ is objective function represents elements cost of barrage (LE), and is a function of number of vents, $\mathrm{N}$, span of vent, $S$, material of abutment and piers, $M_{\mathrm{ab}}$, material of floor, $\mathrm{M}_{\mathrm{fl}}$ and type of bridge, $\mathrm{Br}_{\mathrm{type}} ; \mathrm{f}_{1}$ is volume of bridge $\left(\mathrm{m}^{3}\right)$ and cost of bridge per unit volume $\left(\mathrm{LE} / \mathrm{m}^{3}\right) ; \mathrm{f}_{2}$ is volume of piers $\left(\mathrm{m}^{3}\right)$ and cost of piers per unit volume $\left(\mathrm{LE} / \mathrm{m}^{3}\right) ; \mathrm{f}_{3}$ is volume of abutments $\left(\mathrm{m}^{3}\right)$ and cost of abutment per unit volume $\left(\mathrm{LE} / \mathrm{m}^{3}\right) ; \mathrm{f}_{4}$ is volume of floor $\left(\mathrm{m}^{3}\right)$ and cost of floor per unit volume $\left(\mathrm{LE} / \mathrm{m}^{3}\right) ; \mathrm{c}_{1}, \mathrm{c}_{2}, \mathrm{c}_{3}, \mathrm{c}_{4}$ are functions of $\mathrm{f}_{1}, \mathrm{f}_{2}, \mathrm{f}_{3}, \mathrm{f}_{4}$ respectively; $\mathrm{N}^{l}, \mathrm{~S}^{l}, \mathrm{DBF}^{u}, \mathrm{M}_{\mathrm{ab}}{ }^{l}, \mathrm{M}_{\mathrm{fl}}{ }^{l}, \mathrm{Br}_{\mathrm{type}}{ }^{l}$ are lower boundaries of $\mathrm{N}, \mathrm{S}, \mathrm{DBF}, \mathrm{M}_{\mathrm{ab}}, \mathrm{M}_{\mathrm{fl}}, \mathrm{Br}_{\mathrm{type}}$ respectively; $\mathrm{N}^{u}, \mathrm{~S}^{u}, \mathrm{DBF}^{u}$, $\mathrm{M}_{\mathrm{ab}}{ }^{u}, \mathrm{M}_{\mathrm{fl}}{ }^{u}, \mathrm{Br}_{\text {type }}{ }^{u}$ are upper boundaries of $\mathrm{N}, \mathrm{S}, \mathrm{DBF} \mathrm{M}_{\mathrm{ab}}, \mathrm{M}_{\mathrm{fl}}, \mathrm{Br}_{\mathrm{type}}$ respectively. 
The inputs of the program are:

1. Cross section of canal (Figure 2) includes downstream bed level, DSBL, embankment level, EMB, downstream water level, DSWL, upstream water level, USWL, bed width, BedW, side slope of canal, Z, and discharge, Q.

2. Properties of soil include weight per unit volume, $\gamma_{\text {soil }}$, soil angle, $\Theta_{\text {soil }}$, cohesion of soil, $C_{\text {soil }}$, allowable stresses, $\mathrm{F}_{\text {soil }}$, and Bligh coefficient, $\mathrm{C}_{\mathrm{B}}$.

3. Properties of brick include weight per unit volume, $\gamma_{\text {Brick }}$, allowable compression strength, $F_{b}$, allowable tension strength, $\mathrm{F}_{\mathrm{bt}}$, and cost of brick per unit volume, $\operatorname{Cost}_{\mathrm{m} 3 \mathrm{brick}}{ }^{1}$.

4. Properties of plain concrete include weight per unit volume, $\gamma_{\mathrm{PC}}$, allowable compression strength, $\mathrm{F}_{\mathrm{c}}$, allowable tension strength, $\mathrm{F}_{\mathrm{ct}}$, and cost of plain concrete per unit volume, Cost $\mathrm{m}_{\mathrm{m} 3 \mathrm{PC}}{ }^{2}$.

5. Properties of reinforced concrete include weight per unit volume, $\gamma_{\mathrm{RC}}$, allowable tension strength, $\mathrm{F}_{\mathrm{s}}$, and cost of reinforced concrete per unit volume, $\operatorname{Cost}_{\mathrm{m} 3 \mathrm{RC}}{ }^{3}$.

6. Bridge width, BrW, dead load, DL, live load, LL, and road level, RL.

- Formula (2.a), $0.00 \mathrm{~m} \leq$ heading up $\leq 0.10 \mathrm{~m}$, velocity through vents is between $2 \times \mathrm{V}_{\mathrm{c}}$ and $3 \times \mathrm{V}_{\mathrm{c}}$ are used for determinate $\mathrm{N}, \mathrm{S}, \mathrm{DBF}$.

- The bridge is subject to Live Load, L.L. $=2.50 \mathrm{t} / \mathrm{m}^{2}$ and its own weight to determinate bridge type $\left(\mathrm{Br}_{\text {type }}\right), \mathrm{Road}$ level-Embankment level $\leq 0.50 \mathrm{~m}$ (Figure 3, Figure 4, Figure 5)

- Piers are subjected to water pressure and reactions from bridge; $\mathrm{L}_{\text {pier }}$ is an input parameter, Pier levelUSWL $\geq 0.50 \mathrm{~m}$; the stresses on piers checked to be less than material strength.

- Abutments are subjected to earth pressure and reactions from bridge, the stresses on abutments checked to be less than material strength, the factor of safety against sliding $\geq 2$ for brick and 1.50 for plain concrete.

- Floor subjected to uplift pressure and the load comes from piers and abutments. Formula (5) used for determinate scour length, $\mathrm{L}_{3}$; formula (6) used for determinate total length of the floor $\left(\mathrm{L}_{1}+\mathrm{L}_{2}+\mathrm{L}_{3}\right)$ providing that $0.50 \mathrm{~m}<\mathrm{L}_{1}<10.0 \mathrm{~m}, \mathrm{~L}_{2} \geq \mathrm{L}_{\text {pier }}, \mathrm{C}_{\mathrm{B}}$ value was calculated so as not to change the floor length because the author focus on surface flow, the stresses on floor checked to be less than material strength, the factor of safety against uplift pressure $\geq 1.50$, and the total loads comes from the whole structure must not exceed the allowable stresses for the soil.

$\mathrm{N}, \mathrm{S}, \mathrm{DBF}, \mathrm{L}_{1}, \mathrm{~L}_{2}$ and $\mathrm{L}_{3}$ are calculated according to equations and limits mentioned above; $\mathrm{f}_{1}, \mathrm{c}_{1}$ are calculated for the three types of bridge then choose the minimum cost, $\mathrm{c}_{1} ; \mathrm{f}_{2}, \mathrm{c}_{2}$ are calculated for the three materials of piers after design the pier width according to each material, $\mathrm{E}$, then choose the minimum cost, $\mathrm{c}_{2} ; \mathrm{f}_{3}, \mathrm{c}_{3}$ are calculated for the three materials of abutment after design the top thickness, Tat, and bottom thickness, Tab, according to each material then choose the minimum cost, $c_{3} ; \mathrm{f}_{4}, \mathrm{c}_{4}$ are calculated for the three materials of floor after design the reinforced thickness, $\mathrm{T}_{1 \mathrm{RC}}, \mathrm{T}_{2 \mathrm{RC}}, \mathrm{T}_{3 \mathrm{RC}}$ and plain concrete thickness, $\mathrm{T}_{1 \mathrm{PC}}, \mathrm{T}_{2 \mathrm{PC}}, \mathrm{T}_{3 \mathrm{PC}}$, according to each material then choose the minimum cost, $\mathrm{c}_{4}$; after that calculate $\mathrm{c}\left(\mathrm{N}, \mathrm{S}, \mathrm{DBF}, \mathrm{M}_{\mathrm{ab}}, \mathrm{M}_{\mathrm{fl}}, \mathrm{Br}_{\mathrm{type}}\right)$; then make another trial for another values of N, S, DBF; Finally, choose the minimum total cost.

\section{Results and Discussion:-}

The solution database was generated by varying the eighteen variables; the range of variables shown in Table1. For the sake of illustration, the comparison between the updated cost for an existing structure and its cost using the ODR-SCE software are presented in Table 2.

It is obviously seen that the ODR-SCE software is very effective (the ranges varies from $11 \%$ to 64\%). For knowing the difference between the actual design and the optimal one Table 3, Table 4, Table 5 were performed; the optimal material for abutment and piers is plain concrete; the optimal one for floor is using two layers; the upper one is reinforced concrete and the lower one is plain concrete; the optimal type of bridge is slab type. There is very big change in choosing $\mathrm{N}, \mathrm{S}$ without marked change in the multiplying of $\mathrm{N} \times \mathrm{S}$ (No. of vents $\times$ Span of vents), for example, the optimal program chooses $\mathrm{N}=3, \mathrm{~S}=4.00 \mathrm{~m}(3 \times 4.00=12.00 \mathrm{~m})$ instead of $\mathrm{N}=2, \mathrm{~S}=5.50 \mathrm{~m}(2 \times 5.50=11.00 \mathrm{~m})$ for ST-4 Regulator (Table 3, Table 5), which led to increase of piers numbers with reduction in the cost (29\%) because the reduction caused by changing floor material from RC to $\mathrm{PC}+\mathrm{RC}$ and by changing pier and abutment materials from $\mathrm{RC}$ to $\mathrm{PC}, \mathrm{N}=2, \mathrm{~S}=5.00 \mathrm{~m}(2 \times 5.00=10.00 \mathrm{~m})$ instead of $\mathrm{N}=5, \mathrm{~S}=2.40 \mathrm{~m}(5 \times 2.40=12.00 \mathrm{~m})$ for $\mathrm{ST}-6$ Regulator (Table 3, Table 5), which led to reduction of piers numbers and floor width, thus, $43 \%$ reduction of the cost.

\footnotetext{
${ }^{1} \mathrm{Cost}_{\mathrm{m} 3 \text { brick }}=200 \mathrm{LE} / \mathrm{m}^{3}$

${ }^{2} \mathrm{Cost}_{\mathrm{m} 3 \mathrm{PC}}=500 \mathrm{LE} / \mathrm{m}^{3}$

${ }^{3}$ Cost $_{\mathrm{m} 3 \mathrm{RC}}=2000 \mathrm{LE} / \mathrm{m}^{3}$
} 
On the other hand, the results showed very marked change in the multiplying of $\mathrm{N} \times \mathrm{S}$, which illustrates very huge fault in hydraulic design. For example, the optimal program chooses $\mathrm{N}=3, \mathrm{~S}=3.00 \mathrm{~m}(3 \times 3.00=9.00 \mathrm{~m})$ instead of $\mathrm{N}=4, \mathrm{~S}=3.00 \mathrm{~m}(4 \times 3.00=12.00 \mathrm{~m})$ for ST-1 Regulator (Photo2, Table 3, Table 5), which led to reduce the floor width and the number of piers, thus, $11 \%$ reduction of the cost, $\mathrm{N}=3, \mathrm{~S}=3.00 \mathrm{~m}(3 \times 3.00=9.00 \mathrm{~m})$ instead of $\mathrm{N}=3, \mathrm{~S}=5.00 \mathrm{~m}$ $(3 \times 5.00=15.00 \mathrm{~m})$ for ST-2 Regulator (Photo3, Table 3, Table 5), which led to reduce floor width, thus, $14 \%$ reduction of the cost, $\mathrm{N}=3, \mathrm{~S}=6.00 \mathrm{~m}(3 \times 6.00=18.00 \mathrm{~m})$ instead of $\mathrm{N}=6, \mathrm{~S}=5.00 \mathrm{~m}(6 \times 5.00=30.00 \mathrm{~m})$ for ST-3 Regulator (Photo4, Table 3, Table 5), which led to reduce the floor width and the number of piers, thus, $21 \%$ reduction of the cost, $\mathrm{N}=3, \mathrm{~S}=3.00 \mathrm{~m}(3 \times 3.00=9.00 \mathrm{~m})$ instead of $\mathrm{N}=4, \mathrm{~S}=3.50 \mathrm{~m}(4 \times 3.50=14.00 \mathrm{~m})$ for ST -5 Regulator (Photo5, Table 3, Table 5), which led to reduce the floor width and the number of piers, thus, 33\% reduction of the cost, $\mathrm{N}=2, \mathrm{~S}=6.00 \mathrm{~m}(2 * 6.00=12.00 \mathrm{~m})$ instead of $\mathrm{N}=6, \mathrm{~S}=3.00 \mathrm{~m}(6 \times 3.00=18.00 \mathrm{~m})$ for ST-7 Regulator (Photo6, Table $4^{4}$, Table 5,

Figure 8 , Figure $9^{5}$ ), which led to reduce the floor width and the number of piers, but $64 \%$ reduction of the cost comes from the change of piers and abutment material from RC to PC and the change of floor material from RC to $\mathrm{RC}+\mathrm{PC}$.

The impacts of every regulator element cost on the whole cost of all elements have been recorded for all the selected seven examples (Chart 1); for instant, the impact of bridge is between $4 \%$ and $11 \%$ with average value of $6 \%$, the impact of piers is between $3 \%$ and $8 \%$ with average value of $6 \%$, the impact of abutments is between $21 \%$ and $35 \%$ with average value of $27 \%$, and the impact of floor is between $54 \%$ and $69 \%$ with average value of $61 \%$.

We deduced an empirical equation to estimate the optimal cost of regulator elements (Chart 2); the equation is $0.429 \times\left(\mathrm{N} \times \mathrm{S} \times \mathrm{H}_{\mathrm{DS}} \times \mathrm{L}\right)^{2}-316.3 \times \mathrm{N} \times \mathrm{S} \times \mathrm{H}_{\mathrm{DS}} \times \mathrm{L}+2 \mathrm{E} 6$.

${ }^{4}$ ST-7 has special case whereas the abutments were covered with brick $(25 \mathrm{~cm})$ from one side and the piers were covered with brick $(25 \mathrm{~cm})$ from both sides.

${ }^{5}$ Figure 8, Figure 9 illustrates the dimensions of structure No.7 (ST-7) shown in Table 4, Table 5 as an example for the studied seven structures. 


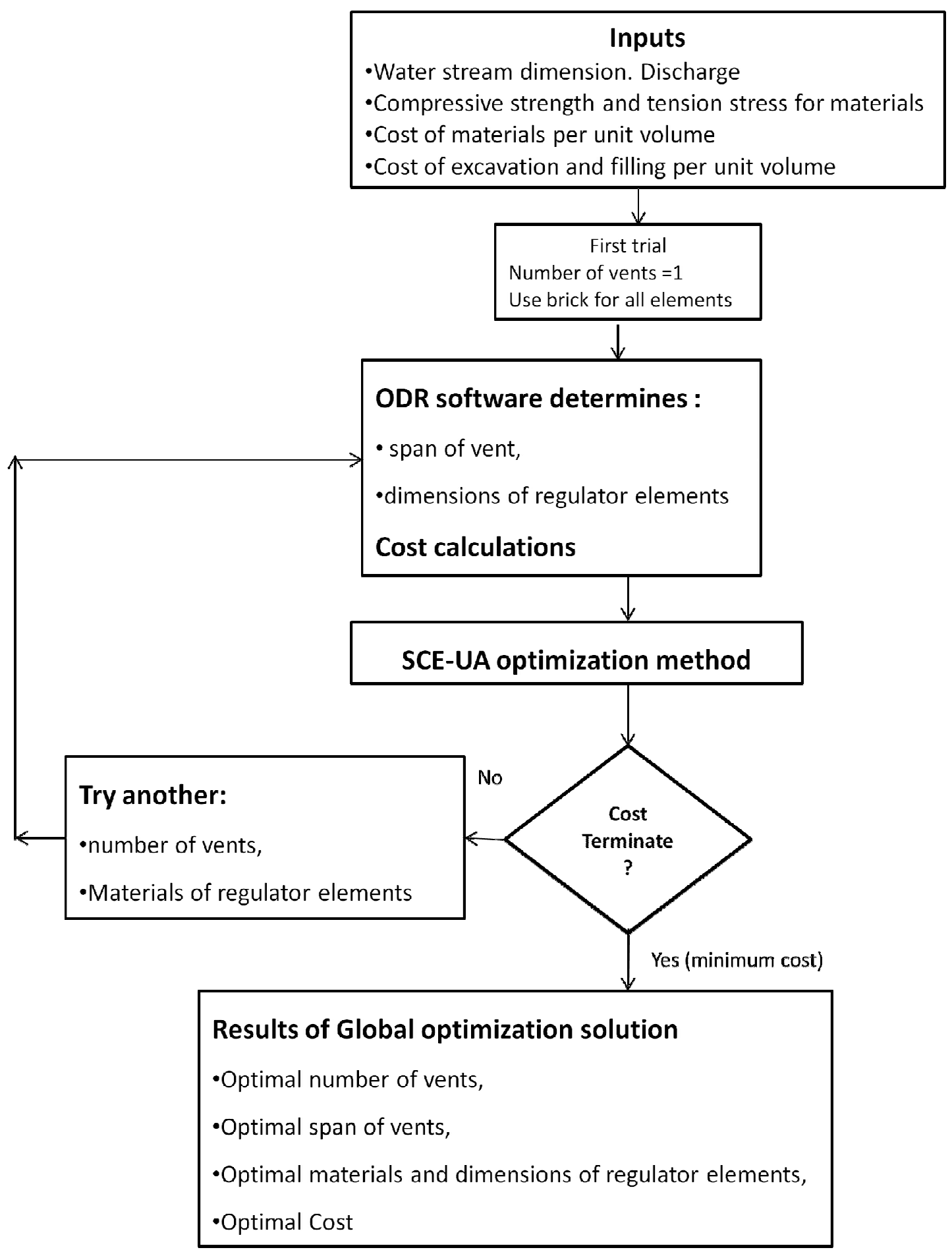

Figure 1:- Typical Flow chart designed and used in the study. 


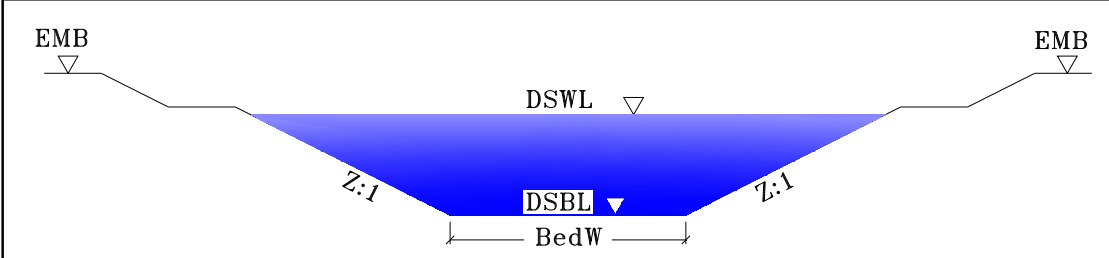

Figure 2:- Cross section of the canal

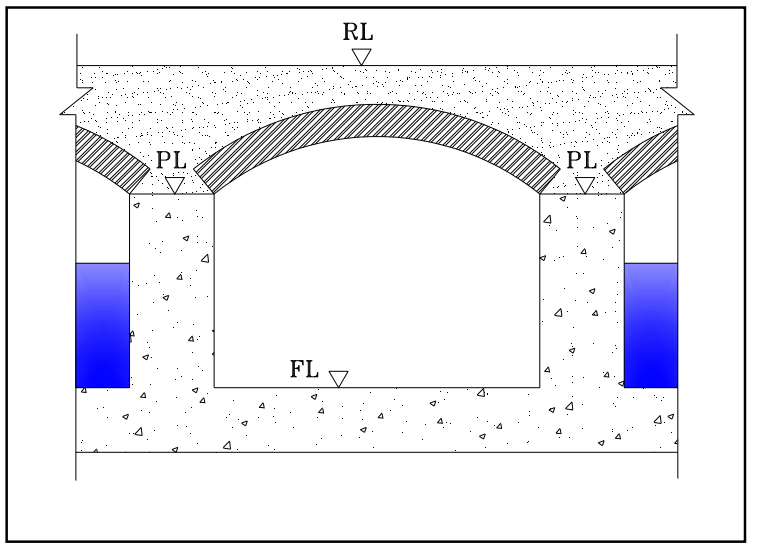

Figure 3:- Cross section of bridge type No.1 (arch bridge)

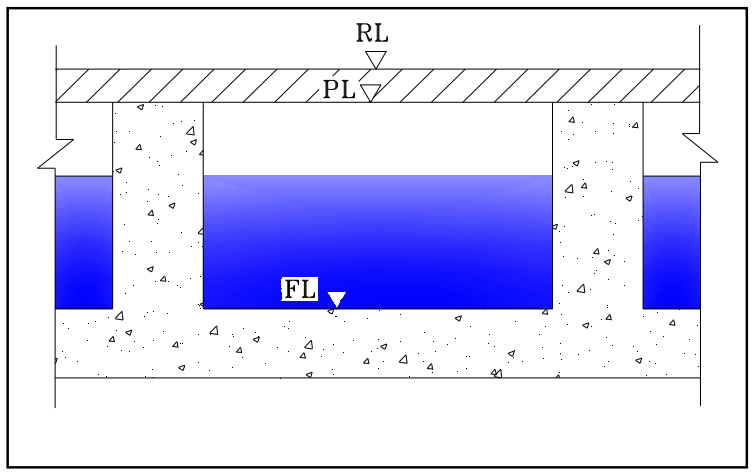

Figure 4:- Cross section of bridge type No.2 (Slab Bridge)

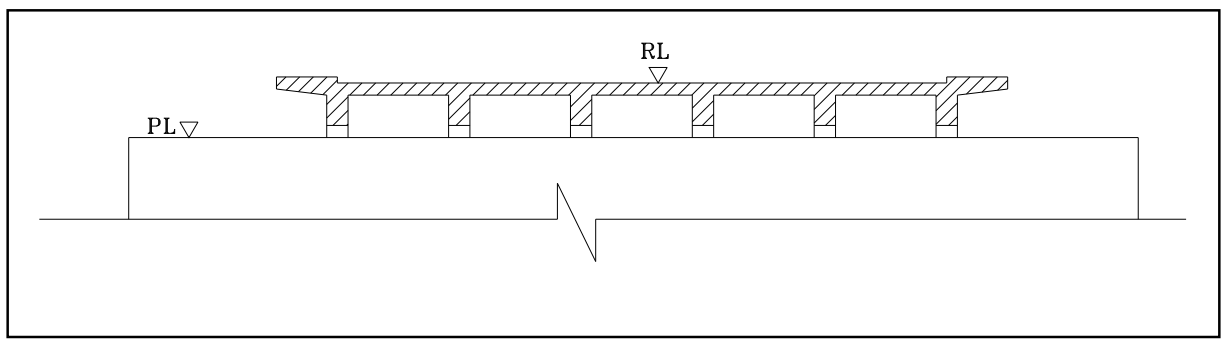

Figure 5:- Cross section of Bridge type No.3 (Beam type) 


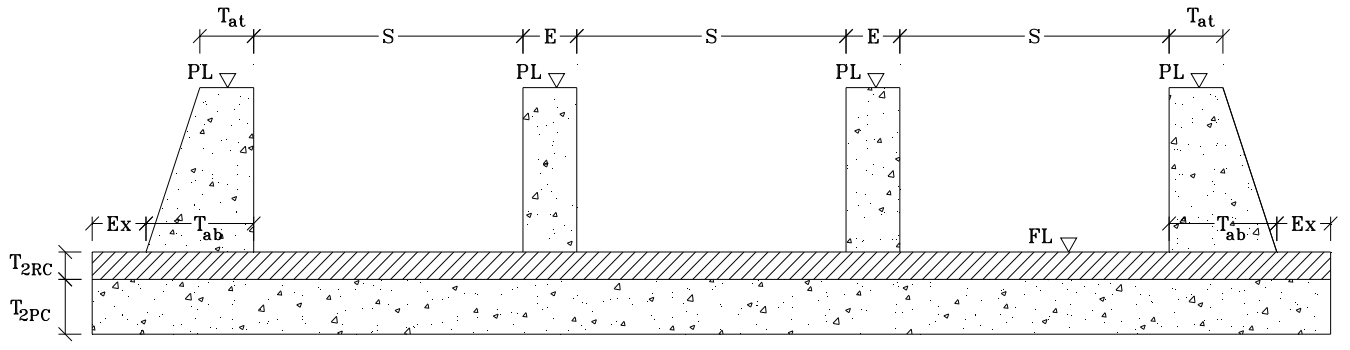

Figure 6:- Cross section of the regulator illustrates the symbols $T_{a t}, T_{a b}, E, S, T_{2 P C}$ and $T_{2 R C}$.

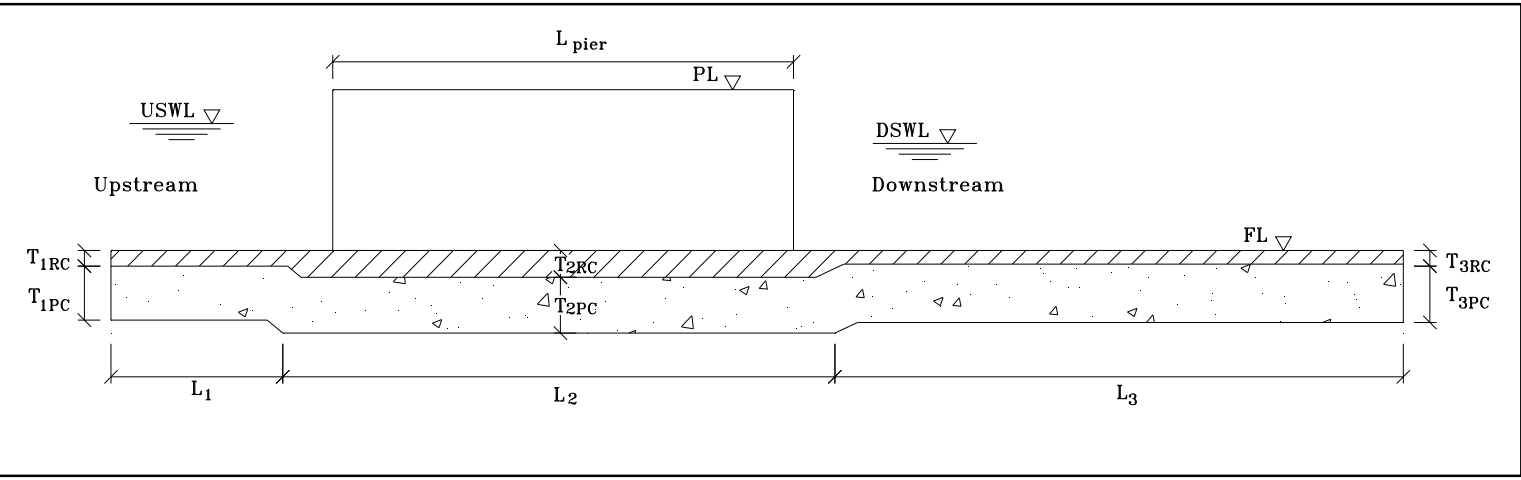

Figure 7:- Longitudinal section of the regulator illustrates symbols $L_{\text {pier }}, L_{1}, L_{2}, L_{3}, T_{1 P C}, T_{1 R C}, T_{2 P C}, T_{2 R C}, T_{3 P C}$ and $\mathrm{T}_{3 \mathrm{RC}}$.

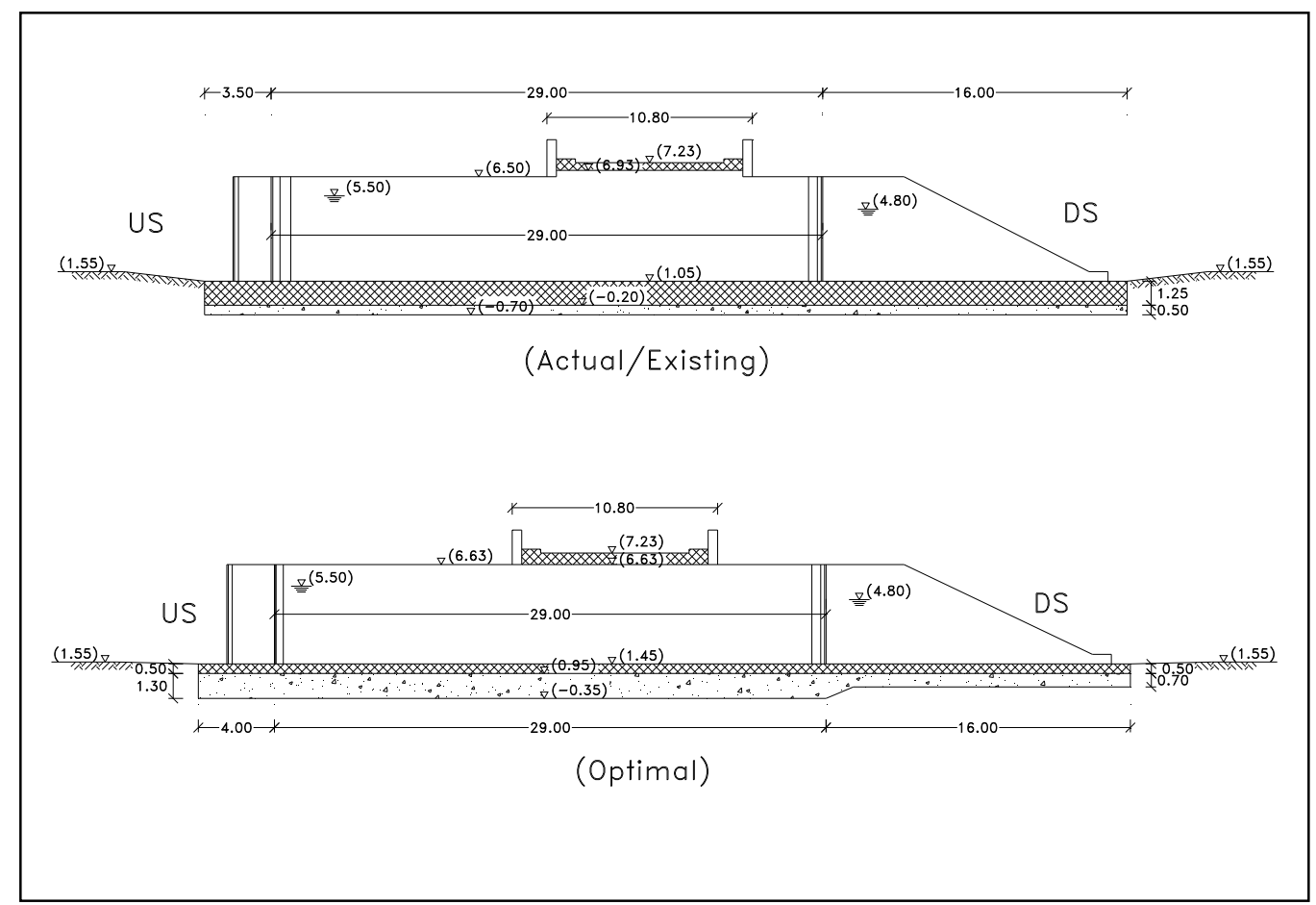

Figure 8:- Comparison between optimal and actual longitudinal sections for ST-7 (1998) 


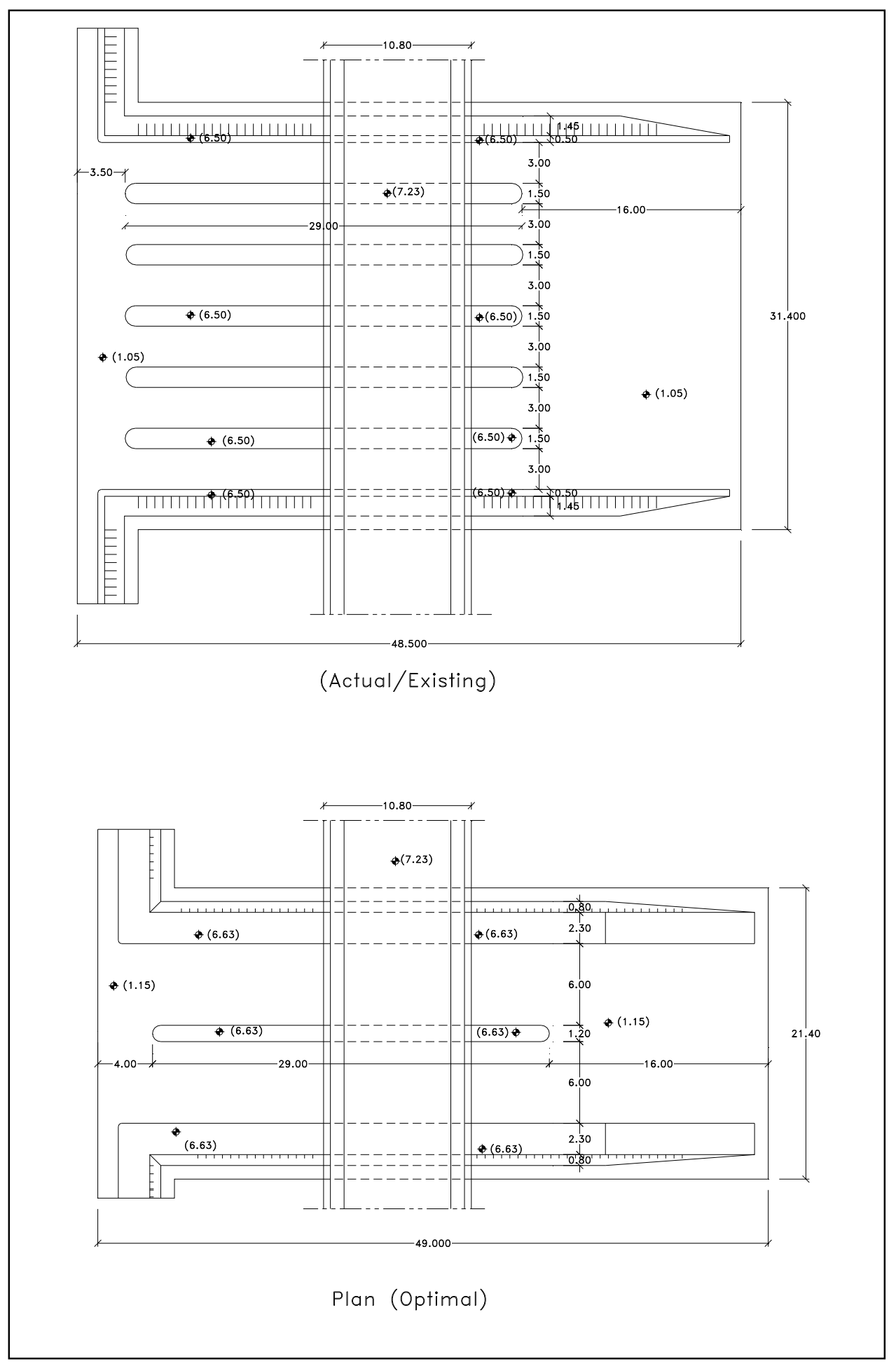

Figure 9 :- Comparison between optimal and actual plans for ST-7 (1998) 


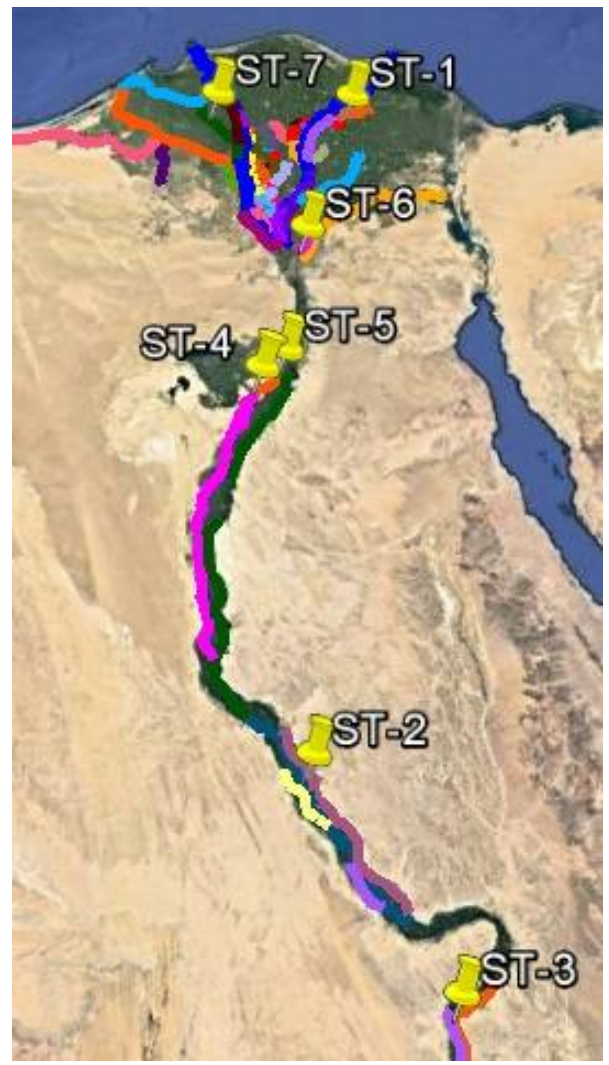

Photo 1:- Google earth photo illustrates the seven evaluated regulators

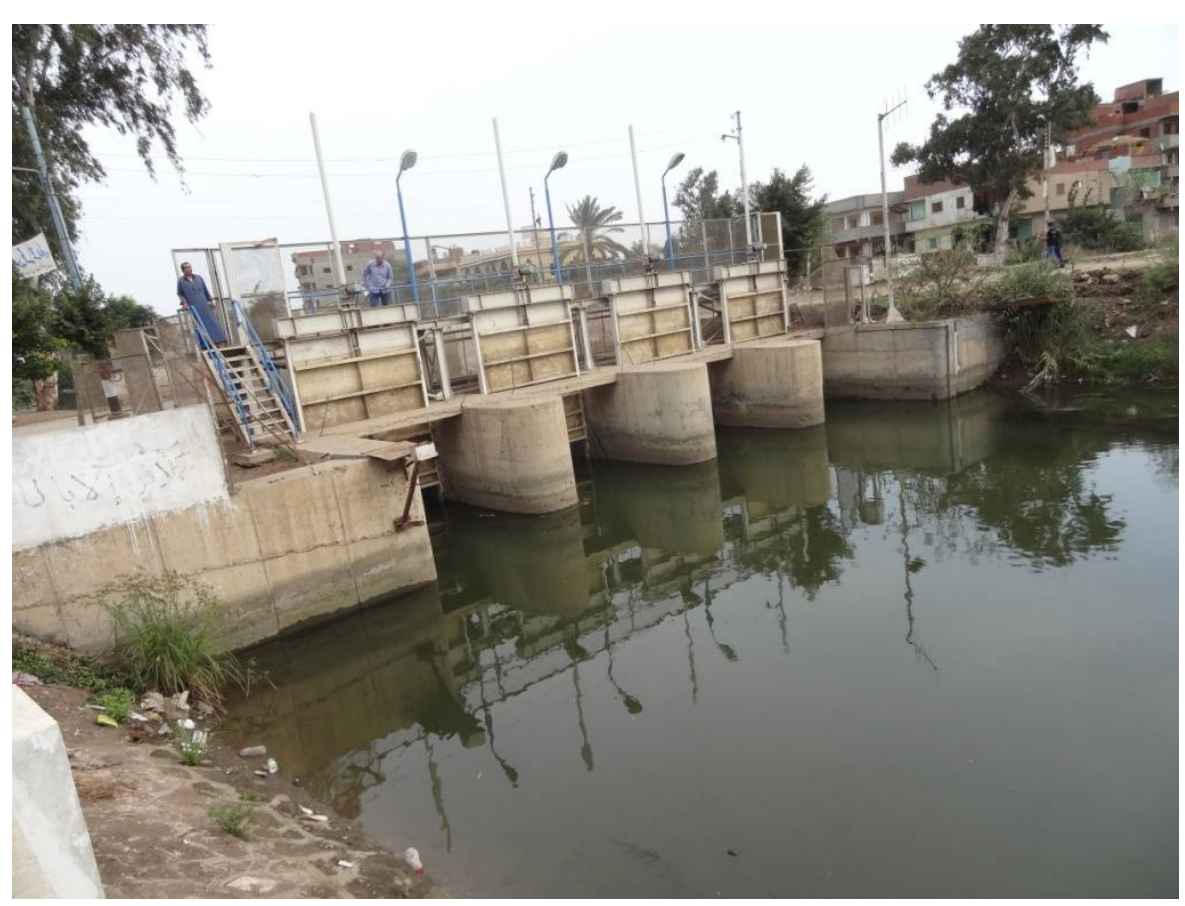

Photo2:- U.S. View of ST-1 shows all gates are fully opened (at W.L. less than the minimum designed W.L.) 


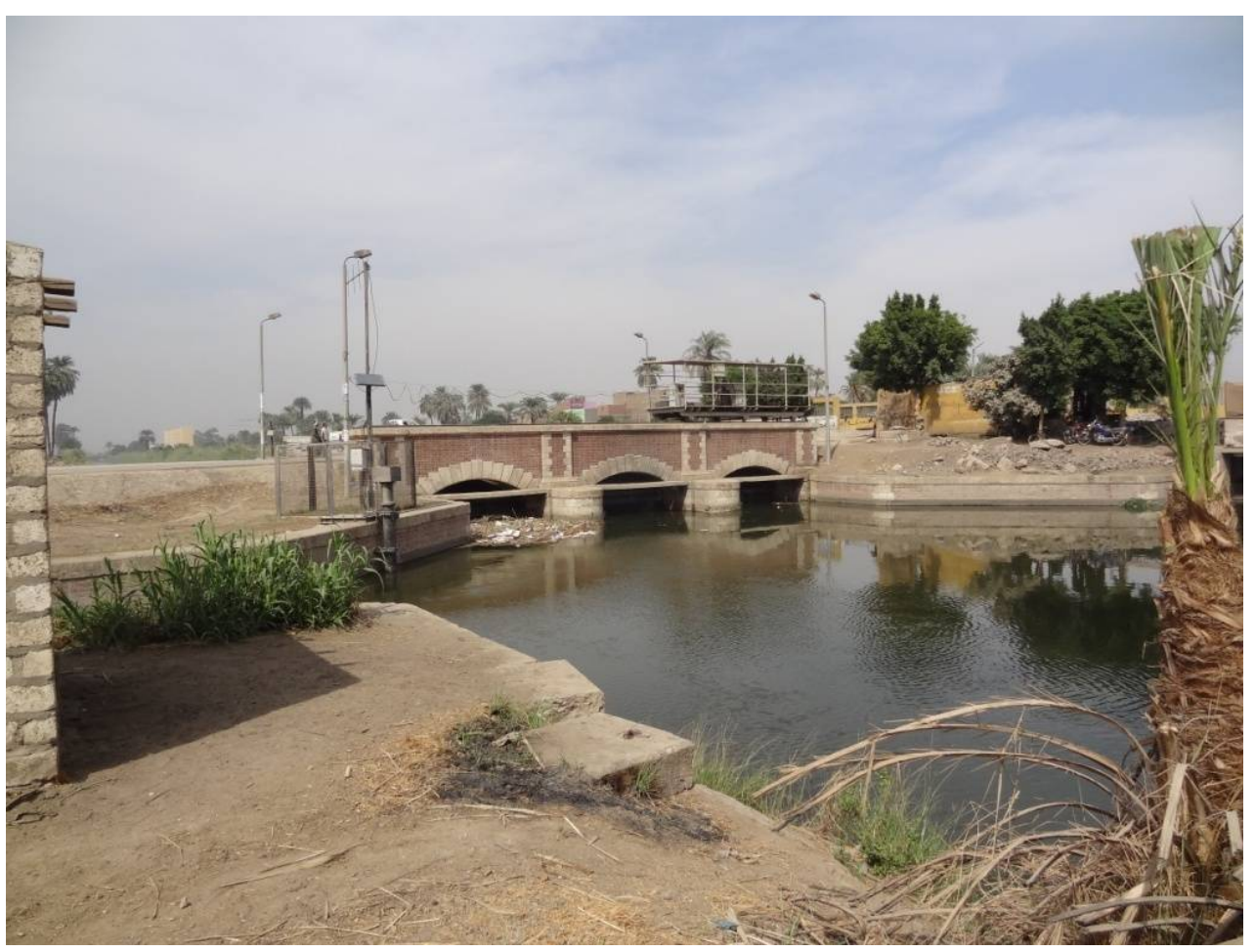

Photo3:- U.S. View of ST-2 shows continuing closed third gate

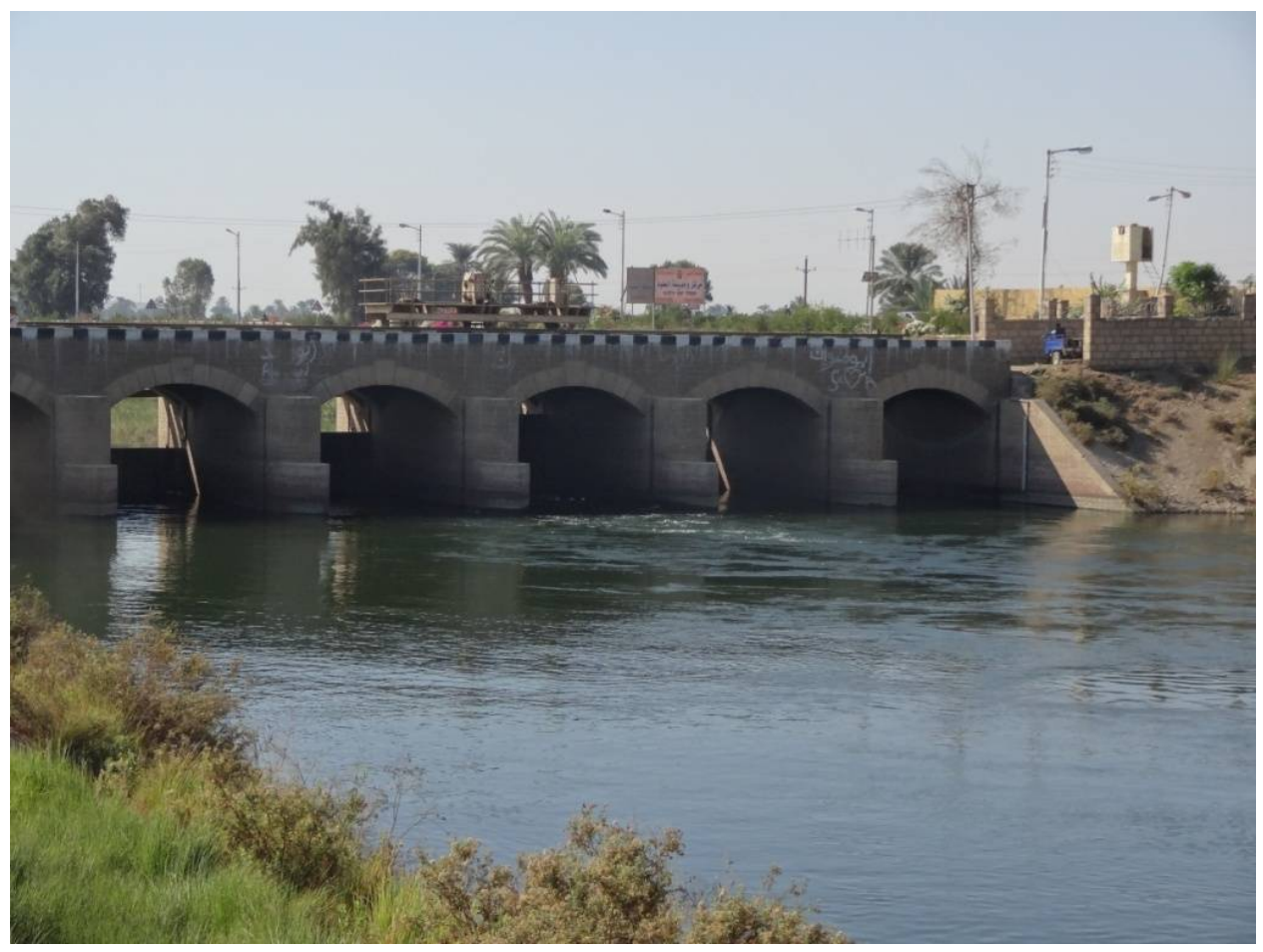

Photo4:- U.S. View ST-3 shows all gates are partially opened 


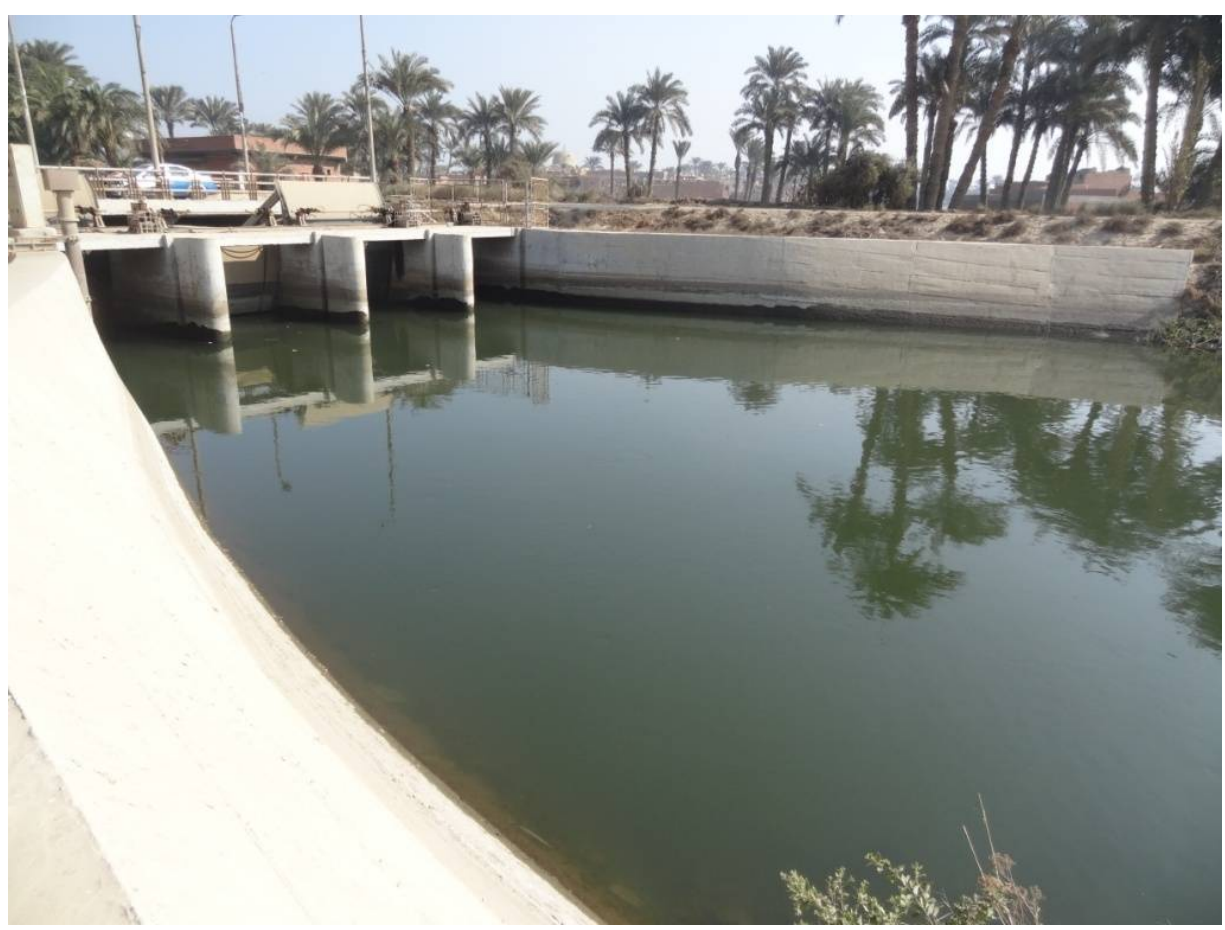

Photo5:- U.S. View of ST-5 shows fully closed two gates and fully opened two gates

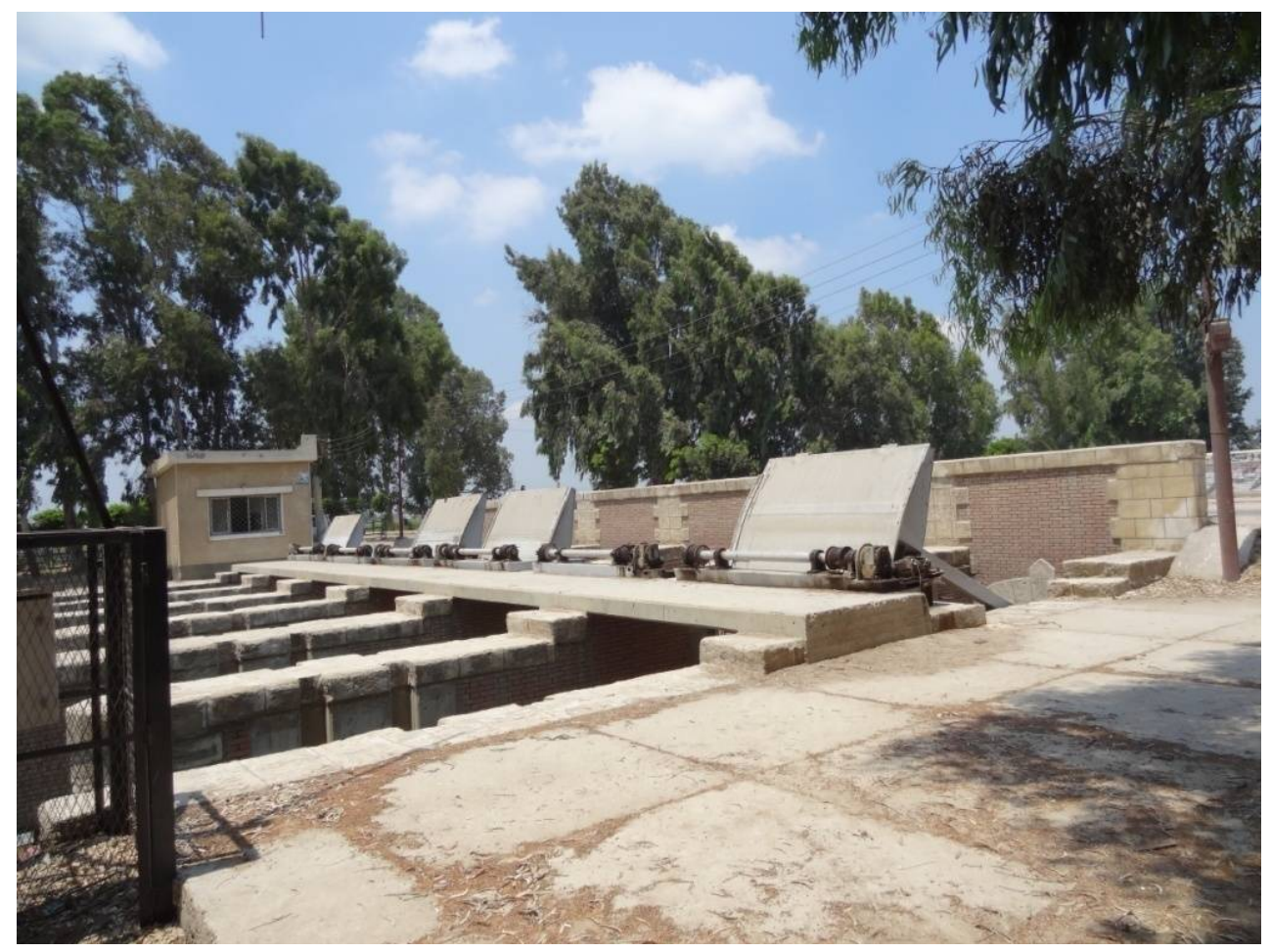

Photo6:- U.S. View ST-7 shows continuing closed two gates 


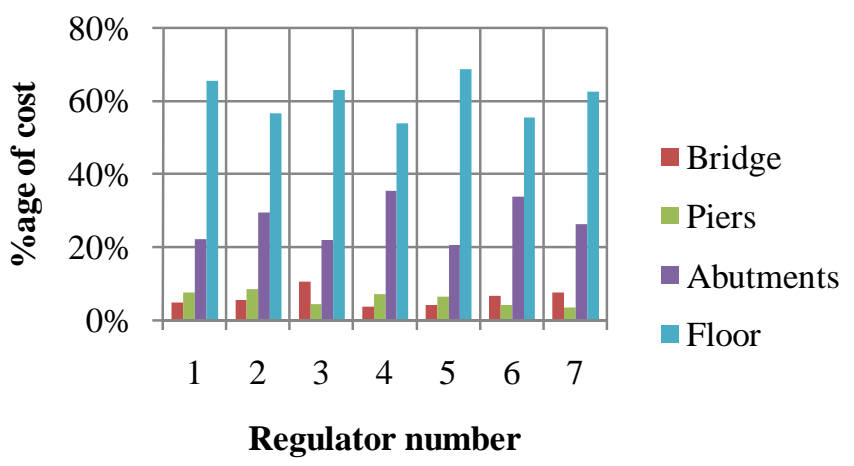

Chart 1:- The impact of regulator elements on the total cost.

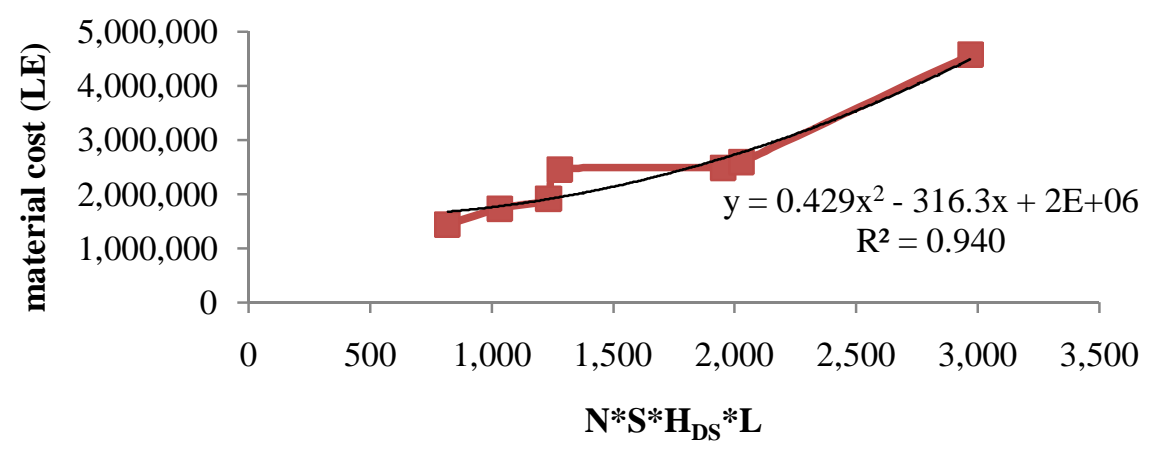

Chart 2:- The relation between $\mathrm{N} * \mathrm{~S} * \mathrm{H}_{\mathrm{DS}} * \mathrm{~L}$ and material cost.

Table1:- Parameters, and intervals of cycles

\begin{tabular}{|c|c|c|c|c|c|}
\hline & Symbol & Definitions & Intervals of cycles & Rate of intervals & No. of cycles \\
\hline \multicolumn{6}{|c|}{ independent variables } \\
\hline 1 & $\mathrm{~S}$ & Span of vent & from $2.00 \mathrm{~m}$ to $9.00 \mathrm{~m}$ & 1 & 8 \\
\hline 2 & $\mathrm{~N}$ & Numbers of spans & from 2 to 50 & 1 & 49 \\
\hline 3 & $\mathrm{DBF}$ & $\begin{array}{l}\text { The difference between bed level } \\
\text { and floor level }\end{array}$ & from $0.00 \mathrm{~m}$ to $0.50 \mathrm{~m}$ & 0.1 & 5 \\
\hline 4 & $\mathrm{M}_{\mathrm{ab}}$ & Pier and abutment Materials & 1 Brick, 2 PC, 3 RC & 1 & 3 \\
\hline 5 & $\mathrm{M}_{\mathrm{fl}}$ & Floor Materials & $2 \mathrm{PC}, 3 \mathrm{RC}, 4 \mathrm{PC}+\mathrm{RC}$ & 1 & 3 \\
\hline 6 & $\mathrm{Br}_{\text {type }}$ & Type of bridge & 1 Arch, 2 Slab, 3 Beam & 1 & 3 \\
\hline \multicolumn{6}{|c|}{ dependant variables/ dimensions } \\
\hline 1 & $\mathrm{E}$ & Pier width & form $0.50 \mathrm{~m}$ to $3.00 \mathrm{~m}$ & 0.1 & 25 \\
\hline 2 & $\mathrm{~T}_{\mathrm{at}}$ & Top width of abutment & form $0.50 \mathrm{~m}$ to $3.00 \mathrm{~m}$ & 0.1 & 25 \\
\hline 3 & $\mathrm{~T}_{\mathrm{ab}}$ & Bottom width of abutment & form $0.50 \mathrm{~m}$ to $10.00 \mathrm{~m}$ & 0.1 & 95 \\
\hline 4 & $\mathrm{~T}_{1 \mathrm{PC}}$ & Floor PC thickness & form $0.50 \mathrm{~m}$ to $3.00 \mathrm{~m}$ & 0.1 & 25 \\
\hline 5 & $\mathrm{~T}_{1 \mathrm{RC}}$ & US floor RC thickness & form $0.50 \mathrm{~m}$ to $3.00 \mathrm{~m}$ & 0.1 & 25 \\
\hline 6 & $\mathrm{~T}_{2 \mathrm{PC}}$ & Middle floor PC thickness & form $0.50 \mathrm{~m}$ to $3.00 \mathrm{~m}$ & 0.1 & 25 \\
\hline 7 & $\mathrm{~T}_{2 \mathrm{RC}}$ & Middle floor PC thickness & form $0.50 \mathrm{~m}$ to $3.00 \mathrm{~m}$ & 0.1 & 25 \\
\hline 8 & $\mathrm{~T}_{3 \mathrm{PC}}$ & DS floor PC thickness & form $0.50 \mathrm{~m}$ to $3.00 \mathrm{~m}$ & 0.1 & 25 \\
\hline 9 & $\mathrm{~T}_{3 \mathrm{RC}}$ & DS floor RC thickness & form $0.50 \mathrm{~m}$ to $3.00 \mathrm{~m}$ & 0.1 & 25 \\
\hline \multicolumn{6}{|c|}{ calculated parameters } \\
\hline 1 & $\mathrm{~L}_{1}$ & US floor length & form $0.50 \mathrm{~m}$ to $10.00 \mathrm{~m}$ & 0.5 & 19 \\
\hline 2 & $\mathrm{~L}_{2}$ & Middle floor length & form $5.00 \mathrm{~m}$ to $30.00 \mathrm{~m}$ & 0.5 & 50 \\
\hline 3 & $\mathrm{~L}_{3}$ & DS floor length & form $5.00 \mathrm{~m}$ to $30.00 \mathrm{~m}$ & 0.5 & 50 \\
\hline \multicolumn{3}{|c|}{ Total number of trials } & & & $364 \mathrm{E}+20$ \\
\hline
\end{tabular}


Table 2:- Comparison between the estimated costs for the existing structures and their optimal costs using the multimodel solution.

\begin{tabular}{|l|l|l|l|}
\hline & Cost & \multicolumn{3}{l|}{} \\
\hline Name & estimated (LE) & optimal(LE) & $\%$ Age Reduction \\
\hline ST-1 & $1,951,255$ & $1,743,800$ & $11 \%$ \\
\hline ST-2 & $1,685,439$ & $1,450,138$ & $14 \%$ \\
\hline ST-3 & $3,174,225$ & $2,495,640$ & $21 \%$ \\
\hline ST-4 & $6,477,828$ & $4,575,320$ & $29 \%$ \\
\hline ST-5 & $2,853,950$ & $1,923,328$ & $33 \%$ \\
\hline ST-6 & $4,309,911$ & $2,455,890$ & $43 \%$ \\
\hline ST-7 & $7,297,355$ & $2,599,908$ & $64 \%$ \\
\hline
\end{tabular}

Table 3:- The actual dimensions, materials, volumes and the updated costs for the existing structures (from ST-1 to \begin{tabular}{|l|l|l|l}
\multicolumn{4}{|c}{ ST-6). } \\
\hline Symbol & ST-1 & ST-2 & ST-3
\end{tabular}

\begin{tabular}{|c|c|c|c|c|c|c|}
\hline Symbol & ST-1 & ST-2 & ST-3 & ST-4 & ST-5 & ST-6 \\
\hline $\mathrm{S}$ & 3.00 & 5.00 & 5.00 & 5.50 & 3.50 & 2.40 \\
\hline $\mathrm{N}$ & 4 & 3 & 6 & 2 & 4 & 5 \\
\hline DBF & 0.50 & 0.00 & 0.50 & 0.00 & 0.50 & 1.50 \\
\hline $\mathrm{M}_{\mathrm{ab}}{ }^{6}$ & 2 & 2 & 2 & 3 & 3 & 2 \\
\hline $\mathrm{M}_{\mathrm{fl}}{ }^{7}$ & 4 & 4 & 4 & 3 & 4 & 4 \\
\hline $\mathrm{Br}_{\text {type }}^{8}$ & 2 & 3 & 3 & 2 & 2 & 2 \\
\hline $\mathrm{E}$ & 1.50 & 1.75 & 1.50 & 1.60 & 0.60 & 2.00 \\
\hline $\mathrm{T}_{\mathrm{at}}$ & 1.00 & 2.00 & 1.00 & 1.30 & 0.60 & 1.03 \\
\hline $\mathrm{T}_{\mathrm{ab}}$ & 2.20 & 3.00 & 3.50 & 1.30 & 0.75 & 5.00 \\
\hline $\mathrm{T}_{1 \mathrm{PC}}$ & 1.00 & 0.75 & 0.50 & 0.00 & 0.60 & 2.35 \\
\hline $\mathrm{T}_{1 \mathrm{RC}}$ & 0.50 & 0.50 & 0.50 & 1.10 & 0.80 & 0.25 \\
\hline $\mathrm{T}_{2 \mathrm{PC}}$ & 1.00 & 0.75 & 0.50 & 0.00 & 0.60 & 2.35 \\
\hline $\mathrm{T}_{2 \mathrm{RC}}$ & 0.50 & 0.50 & 0.50 & 2.20 & 0.80 & 0.25 \\
\hline $\mathrm{T}_{3 \mathrm{PC}}$ & 1.00 & 0.75 & 0.50 & 0.00 & 0.60 & 2.35 \\
\hline $\mathrm{T}_{3 \mathrm{RC}}$ & 0.50 & 0.50 & 0.50 & 1.50 & 0.80 & 0.25 \\
\hline $\begin{array}{l}L_{\text {pier }} \\
\end{array}$ & 22.00 & 19.00 & 16.50 & 26.00 & 23.75 & 20.00 \\
\hline $\mathrm{L}_{1}$ & 2.00 & 2.00 & 5.00 & 9.10 & 5.50 & 7.00 \\
\hline $\mathrm{L}_{2}$ & 22.00 & 19.00 & 16.50 & 26.00 & 24.00 & 21.00 \\
\hline $\mathrm{L}_{3}$ & 14.00 & 5.25 & 11.50 & 18.00 & 18.00 & 14.00 \\
\hline $\mathrm{BrW}$ & 10.00 & 10.00 & 10.00 & 12.50 & 10.00 & 12.00 \\
\hline PL & 5.35 & 57.40 & 79.60 & 28.95 & 26.20 & 21.35 \\
\hline FL & 0.50 & 51.70 & 72.80 & 20.50 & 21.58 & 12.00 \\
\hline Wf & 22.90 & 26.50 & 46.50 & 17.20 & 19.30 & 32.00 \\
\hline $\mathrm{Vol}_{\mathrm{Br}}$ & 55.50 & 82.68 & 165.23 & 100.38 & 62.30 & 63.36 \\
\hline Vol $_{\text {Piers }}$ & 480.15 & 379.05 & 841.50 & 351.52 & 197.51 & 1496.00 \\
\hline Vol $_{\text {Abut. }}$ & 589.76 & 748.12 & 1009.80 & 1166.61 & 296.26 & 2367.98 \\
\hline $\mathrm{Vol}_{\mathrm{flPC}}$ & 870.20 & 521.72 & 767.25 & 0.00 & 550.05 & 3158.40 \\
\hline Vol $_{\text {flRC }}$ & 435.10 & 347.81 & 767.25 & 1620.41 & 733.40 & 336.00 \\
\hline $\operatorname{Cost}_{\mathrm{Br}}$ & 111,000 & 165,368 & 330,450 & 200,750 & 124,600 & 126,720 \\
\hline Cost $_{\text {Piers }}$ & 240,075 & 189,525 & 420,750 & 703,040 & 395,010 & 748,000 \\
\hline Cost $_{\text {Abut. }}$ & 294,880 & 374,063 & 504,900 & $2,333,214$ & 592,515 & $1,183,991$ \\
\hline Cost & $1,305,300$ & 956,484 & $1,918,125$ & $3,240,824$ & $1,741,825$ & $2,251,200$ \\
\hline Total Cost & $1,951,255$ & $1,685,439$ & $3,174,225$ & $6,477,828$ & $2,853,950$ & $4,309,911$ \\
\hline
\end{tabular}

${ }^{6} \mathrm{M}_{\mathrm{ab}}=1$ Brick, 2 PC, $3 \mathrm{RC}$

${ }^{7} \mathrm{M}_{\mathrm{fl}}=2 \mathrm{PC}, 3 \mathrm{RC}, 4 \mathrm{PC}+\mathrm{RC}$

${ }^{8} \mathrm{Br}_{\text {type }}=1$ arch bridge, 2 slab bridge, 3 beam bridge 
Table 4:- The actual dimensions, materials, volumes and the updated costs for the existing structures (ST-7).

\begin{tabular}{|c|c|}
\hline Symbol & ST-7 \\
\hline$S$ & 3.00 \\
\hline $\mathrm{N}$ & 6 \\
\hline DBF & 0.50 \\
\hline $\mathrm{M}_{\mathrm{ab}}$ & 3 \\
\hline $\mathrm{M}_{\mathrm{fl}}$ & 3 \\
\hline $\mathrm{Br}_{\text {type }}$ & 2 \\
\hline $\mathrm{E}$ & 1.50 \\
\hline $\mathrm{T}_{\mathrm{at}}$ & 0.50 \\
\hline $\mathrm{T}_{\mathrm{ab}}$ & 1.95 \\
\hline $\mathrm{T}_{1 \mathrm{PC}}$ & 0.50 \\
\hline $\mathrm{T}_{1 \mathrm{RC}}$ & 1.25 \\
\hline $\mathrm{T}_{2 \mathrm{PC}}$ & 0.50 \\
\hline $\mathrm{T}_{2 \mathrm{RC}}$ & 1.25 \\
\hline $\mathrm{T}_{3 \mathrm{PC}}$ & 0.50 \\
\hline $\mathrm{T}_{3 \mathrm{RC}}$ & 1.25 \\
\hline $\mathrm{L}_{\text {pier }}$ & 29.00 \\
\hline $\mathrm{L}_{1}$ & 3.50 \\
\hline $\mathrm{L}_{2}$ & 29.00 \\
\hline $\mathrm{L}_{3}$ & 16.00 \\
\hline BrW & 10.80 \\
\hline PL & 6.93 \\
\hline FL & 1.05 \\
\hline Wf & 31.40 \\
\hline VolBr. & 89.10 \\
\hline Vol $_{\text {Piers }}$ & $\begin{array}{l}\text { (volume of RC)852.60 } \\
\text { (volume of Brick cover) } 426.30\end{array}$ \\
\hline $\mathrm{Vol}_{\text {Abut. }}$ & $\begin{array}{l}\text { (volume of RC)556.10 } \\
\text { (volume of Brick cover) } 142.59\end{array}$ \\
\hline Vol $_{\text {flPC }}$ & 761.45 \\
\hline $\mathrm{Vol}_{\mathrm{flRC}}$ & 1903.63 \\
\hline $\operatorname{Cost}_{\mathrm{Br}}$ & 178,200 \\
\hline Cost $_{\text {Piers }}$ & $\begin{array}{l}\text { (Cost of RC)1,705,200 } \\
\text { (Cost of Brick cover)85,260 } \\
1,790,460\end{array}$ \\
\hline Cost $_{\text {Abut. }}$ & $\begin{array}{l}\text { (Cost of RC)1,112,202 } \\
\text { (Cost of Brick cover)28,518 } \\
1,140,720\end{array}$ \\
\hline Cost $_{\text {Floor }}$ & $4,187,975$ \\
\hline Total Cost & $7,297,355$ \\
\hline
\end{tabular}


Table 5:- The optimal dimensions, materials, volumes and the optimal costs using the multi-model solution (from ST-1 to ST-7).

\begin{tabular}{|c|c|c|c|c|c|c|c|}
\hline Symbol & ST-1 & ST-2 & \begin{tabular}{|l|} 
ST-3 \\
\end{tabular} & ST-4 & ST-5 & ST-6 & ST-7 \\
\hline $\mathrm{S}$ & 3.00 & 3.00 & 6.00 & 4.00 & 3.00 & 5.00 & 6.00 \\
\hline $\mathrm{N}$ & 3 & 3 & 3 & 3 & 3 & 2 & 2 \\
\hline DBF & 0.00 & 0.20 & \begin{tabular}{|l|}
0.00 \\
\end{tabular} & 0.00 & 0.00 & 0.00 & 0.10 \\
\hline $\mathrm{M}_{\mathrm{ab}}$ & 2 & 2 & 2 & 2 & 2 & 2 & 2 \\
\hline $\mathrm{M}_{\mathrm{fl}}$ & 4 & 4 & 4 & 4 & 4 & 4 & 4 \\
\hline $\mathrm{Br}_{\text {type }}$ & 2 & 2 & 2 & 2 & 2 & 2 & 2 \\
\hline $\mathrm{E}$ & 1.40 & 1.00 & 1.00 & 1.40 & 1.20 & 1.40 & 1.20 \\
\hline $\mathrm{T}_{\mathrm{at}}$ & 2.00 & 1.10 & \begin{tabular}{|l|}
1.90 \\
\end{tabular} & 1.70 & 1.40 & 1.90 & 2.30 \\
\hline $\mathrm{T}_{\mathrm{ab}}$ & 2.60 & 4.00 & 2.90 & 5.00 & 2.50 & 3.60 & 3.10 \\
\hline $\mathrm{T}_{1 \mathrm{PC}}$ & 1.30 & 1.20 & 1.60 & 1.50 & 1.30 & 1.40 & 1.30 \\
\hline $\mathrm{T}_{1 \mathrm{RC}}$ & 0.50 & 0.50 & \begin{tabular}{|l|}
0.50 \\
\end{tabular} & 0.50 & 0.50 & 0.50 & 0.50 \\
\hline $\mathrm{T}_{2 \mathrm{PC}}$ & 1.30 & 1.20 & 1.60 & 1.50 & 1.30 & 1.40 & 1.30 \\
\hline $\mathrm{T}_{2 \mathrm{RC}}$ & 0.50 & 0.50 & \begin{tabular}{|l|}
0.50 \\
\end{tabular} & 0.50 & 0.50 & 0.50 & 0.50 \\
\hline $\mathrm{T}_{3 \mathrm{PC}}$ & 0.70 & 0.20 & \begin{tabular}{|l|}
0.70 \\
\end{tabular} & 1.00 & 0.60 & 0.70 & 0.70 \\
\hline $\mathrm{T}_{3 \mathrm{RC}}$ & 0.50 & 0.50 & \begin{tabular}{|l|}
0.50 \\
\end{tabular} & 0.50 & 0.50 & 0.50 & 0.50 \\
\hline $\mathrm{L}_{\text {pier }}$ & 22.00 & 19.00 & 16.50 & 26.00 & 23.75 & 20.00 & 29.00 \\
\hline $\mathrm{L}_{1}$ & 3.00 & 2.00 & \begin{tabular}{|l|}
6.00 \\
\end{tabular} & 10.00 & 6.00 & 4.00 & 4.00 \\
\hline $\mathrm{L}_{2}$ & 22.00 & 19.00 & 16.50 & 28.00 & 25.00 & 23.00 & 29.00 \\
\hline $\mathrm{L}_{3}$ & 14.00 & 5.00 & 12.00 & 17.00 & 16.00 & 15.00 & 16.00 \\
\hline BrW & 10.00 & 10.00 & 10.00 & 12.50 & 10.00 & 12.00 & 10.80 \\
\hline PL & 5.30 & 57.96 & 79.90 & 29.30 & 26.40 & 20.70 & 6.63 \\
\hline FL & 1.00 & 51.50 & 73.30 & 20.50 & 22.08 & 13.50 & 1.45 \\
\hline $\mathrm{Wf}$ & 19.00 & 21.00 & 27.80 & 26.80 & 18.40 & 20.60 & 21.40 \\
\hline VolBr. & 41.40 & 39.00 & 132.00 & 84.00 & 40.20 & 80.40 & 98.50 \\
\hline Vol $_{\text {Piers }}$ & 264.88 & 245.48 & 217.80 & 640.64 & 246.24 & 201.60 & 180.26 \\
\hline Vol $_{\text {Abut. }}$ & 771.42 & 856.60 & 1092.96 & 3242.80 & 791.86 & 1663.20 & 1370.63 \\
\hline $\mathrm{Vol}_{\mathrm{flPC}}$ & 803.70 & 550.20 & 1234.32 & 1983.20 & 918.16 & 994.98 & 1157.74 \\
\hline $\mathrm{Vol}_{\text {flRC }}$ & 370.50 & 273.00 & 479.55 & 737.00 & 432.40 & 432.60 & 524.30 \\
\hline $\operatorname{Cost}_{\mathrm{Br}}$ & 82,800 & 78,000 & 264,000 & 168,000 & 80,400 & 160,800 & 196,992 \\
\hline Cost $_{\text {Piers }}$ & 132,440 & 122,740 & 108,900 & 320,320 & 123,120 & 100,800 & 90,132 \\
\hline Cost $_{\text {Abut. }}$ & 385,710 & 428,298 & 546,480 & $1,621,400$ & 395,928 & 831,600 & 685,314 \\
\hline Cost $_{\text {Floor }}$ & $1,142,850$ & 821,100 & $1,576,260$ & $2,465,600$ & $1,323,880$ & $1,362,690$ & $1,627,470$ \\
\hline Total Cost & $1,743,800$ & $1,450,138$ & $2,495,640$ & $4,575,320$ & $1,923,328$ & $2,455,890$ & $2,599,908$ \\
\hline
\end{tabular}

\section{Conclusions:-}

The presented methodology of the design is a process to determine materials and dimensions of regulator elements, number of vents, and vent span by matching an existing structure with the newly calculated parameters with iteration/ optimization schemes. This research focuses on the development of a new design method for symmetrical regulators based on surface flow and material types of elements and coupled with a hybrid evolutionary global optimization algorithm, namely Shuffled Complex Evolution (SCE). The SCE algorithm developed at the University of Arizona is reported to be an efficient global optimization method that can be used to handle non-linear problems with high-parameter dimensionality. This approach treats equations as a global optimization problem where the cost function to be minimized is defined as the differences in measured and computed dimensions and materials. The optimal solution (materials and dimensions of regulator elements, number of vents, and vent span) is searched for in the multi-model solution space by the SCE algorithm.

Seven regulators are used to evaluate the prediction accuracy of the developed ODR-SCE tool. The results demonstrate the pronounced performance of the developed tools; this software can help decision-makers to know the optimal hydraulic and structural design in addition to the optimal cost of the barrages. It also illustrates that the slab type is more optimal than arch or beam types for the bridge, plain concrete for abutments and piers is more optimal 
than reinforced concrete; combining reinforced and plain concrete for the floor is more optimal than either one alone.

\section{Acknowledgement:-}

We thank the Ministry of Water Resources and Irrigation (MWRI) of Egypt whose generous information made this work possible.

\begin{tabular}{|c|c|}
\hline \multicolumn{2}{|c|}{ List of Symbols } \\
\hline BedW & Bed Width \\
\hline $\mathrm{Br}_{\text {type }}$ & Type of Bridge \\
\hline $\mathrm{BrW}$ & Bridge Width \\
\hline $\mathrm{C}_{\mathrm{B}}$ & Bligh coefficient \\
\hline $\mathrm{C}_{\mathrm{L}}$ & Lane coefficient \\
\hline Osoil & Soil angle \\
\hline $\mathrm{C}_{\text {soil }}$ & Cohesion of soil \\
\hline Cost $_{\text {Abut. }}$ & Cost of abutments \\
\hline Cost $_{\mathrm{Br}}$ & Cost of bridge \\
\hline Cost $_{\text {Floor }}$ & Cost of floor \\
\hline Cost $_{\mathrm{m} 3 \text { brick }}$ & Cost of brick per unit volume \\
\hline Cost $_{\mathrm{m} 3 \mathrm{PC}}$ & Cost of plain concrete per unit volume \\
\hline Cost $_{\mathrm{m} 3 \mathrm{RC}}$ & Cost of reinforced concrete per unit volume \\
\hline Cost $_{\text {Piers }}$ & Cost of piers \\
\hline DBF & The difference between bed level and floor level \\
\hline DS & Down Stream \\
\hline DSBL & Down Stream Bed Level \\
\hline DSWL & Down Stream Water Level \\
\hline $\mathrm{E}$ & Pier width \\
\hline ECP & Egyptian code of practice \\
\hline EMB & Embankment level \\
\hline $\mathrm{F}_{\mathrm{b}}$ & Allowable compression strength of brick \\
\hline $\mathrm{F}_{\mathrm{bt}}$ & Allowable tension strength of brick \\
\hline $\mathrm{F}_{\mathrm{c}}$ & Allowable compression strength of plain concrete \\
\hline $\mathrm{F}_{\mathrm{ct}}$ & Allowable tension strength of plain concrete \\
\hline FL & Floor Level \\
\hline $\mathrm{F}_{\mathrm{s}}$ & Allowable tension strength of steel \\
\hline $\mathrm{F}_{\text {soil }}$ & Allowable stresses \\
\hline$\gamma_{\text {Brick }}$ & Weight of brick per unit volume \\
\hline$\gamma_{\mathrm{PC}}$ & Weight of plain concrete per unit volume \\
\hline$\gamma_{\mathrm{RC}}$ & Weight of reinforced concrete per unit volume \\
\hline$\gamma_{\text {soil }}$ & Weight of soil per unit volume \\
\hline $\mathrm{H}_{\mathrm{DS}}$ & Down Stream head of water \\
\hline$h_{\max }$ & Difference between USWL and FL \\
\hline $\mathrm{H}_{\mathrm{US}}$ & Up-Stream head of water \\
\hline IS & Indian Standard \\
\hline $\mathrm{L}_{1}$ & Up-Stream floor length \\
\hline $\mathrm{L}_{2}$ & Middle floor length \\
\hline $\mathrm{L}_{3}$ & Down-Stream floor length \\
\hline $\mathrm{L}$ & $\mathrm{L}_{1}+\mathrm{L}_{2}+\mathrm{L}_{3}$ (floor length) \\
\hline $\mathrm{L}_{\text {pier }}$ & Pier Length \\
\hline Ls & Scour length \\
\hline $\mathrm{M}_{\mathrm{ab}}$ & Pier and Abutments Materials \\
\hline $\mathrm{M}_{\mathrm{fl}}$ & Floor Materials \\
\hline $\mathrm{N}$ & Numbers of spans \\
\hline ODR & Optimal Design of Regulator \\
\hline
\end{tabular}




\begin{tabular}{|c|c|}
\hline $\mathrm{PC}$ & Plain Concrete \\
\hline $\mathrm{PC}+\mathrm{RC}$ & Lower layer of plain concrete + above layer of reinforced concrete \\
\hline $\bar{Q}$ & Discharge \\
\hline$\overline{\mathrm{RC}}$ & Reinforced Concrete \\
\hline $\mathrm{S}$ & Span of vent \\
\hline ST & Structure \\
\hline $\mathrm{T}_{1 \mathrm{PC}}$ & Floor PC thickness \\
\hline $\mathrm{T}_{1 \mathrm{RC}}$ & US floor RC thickness \\
\hline $\mathrm{T}_{2 \mathrm{PC}}$ & middle floor PC thickness \\
\hline $\mathrm{T}_{2 \mathrm{RC}}$ & middle floor PC thickness \\
\hline $\mathrm{T}_{3 \mathrm{PC}}$ & DS floor PC thickness \\
\hline $\mathrm{T}_{3 \mathrm{RC}}$ & DS floor RC thickness \\
\hline $\mathrm{T}_{\mathrm{ab}}$ & bottom width of abutment \\
\hline $\mathrm{T}_{\text {at }}$ & top width of abutment \\
\hline US & Up Stream \\
\hline USWL & Up Stream water level \\
\hline $\mathrm{V}_{\mathrm{c}}$ & Velocity throw canal. \\
\hline $\mathrm{Vol}_{\text {Abut }}$ & Volume of abutments. \\
\hline $\mathrm{Vol}_{\mathrm{Br} .}$ & Volume of bridge. \\
\hline Vol $_{\text {flPC }}$ & Volume of plain concrete part of floor. \\
\hline Vol $_{\text {flRC }}$ & Volume of reinforced concrete part of floor. \\
\hline Vol $_{\text {Piers }}$ & Volume of Piers. \\
\hline W.L. & Water level \\
\hline $\mathrm{Z}$ & Side slope of the canal \\
\hline
\end{tabular}

\section{References:-}

1. Cooper, V., et al. (1997). "Evaluation of global optimization methods for conceptual rainfall-runoff model calibration." Water Science and Technology 36(5): 53-60.

2. Duan, Q., et al. (1993). "Shuffled complex evolution approach for effective and efficient global minimization." Journal of optimization theory and applications 76(3): 501-521.

3. Duan, Q., et al. (1992). "Effective and efficient global optimization for conceptual rainfall-runoff models." Water resources research 28(4): 1015-1031.

4. Duan, Q., et al. (1994). "Optimal use of the SCE-UA global optimization method for calibrating watershed models." Journal of hydrology 158(3): 265-284.

5. ECP (2001). Egyptian Code of Practice "Water resources and irrigation works" Volume 3.

6. Franchini, M., et al. (1998). "Global optimization techniques for the calibration of conceptual rainfall-runoff models." Hydrological Sciences Journal 43(3): 443-458.

7. Garg, N., et al. (2002). "Optimal barrage design based on subsurface flow considerations." Journal of irrigation and drainage engineering 128(4): 253-263.

8. Garg, N., et al. (2014). "Design of barrage on heterogeneous and anisotropic soils." Current Science (00113891) 107(11).

9. IS6531:1994 Indian Standard :Canal Head Regulators - Criteria for Design [WRD 14: Water Conductor Systems].

10. IS6966-1:1989 "Indian Standard: Hydraulic design of barrages and weirs - Guidelines, Part 1: Alluvial Reaches [WRD 22: River Training and Diversion Works]."

11. IS11130:1984 Indian Standard: Criteria for Structural Design of Barrages and Weirs [WRD 22: River Training and Diversion Works].

12. Jeon, J.-H., et al. (2014). "Comparison of performance between genetic algorithm and SCE-UA for calibration of SCS-CN surface runoff simulation." Water 6(11): 3433-3456.

13. Jiang, Y. and S. Gong (2012). "Bus holding strategy based on shuffled complex evolution method." Frontiers of Computer Science 6(4): 462-468.

14. Khosla, A., et al. (1936). Design of weirs on permeable foundations.

15. Khosla, A. N. (1932). Pressure pipe observations at Panjnad Weir, Paper. 
16. Kuczera, G. (1997). "Efficient subspace probabilistic parameter optimization for catchment models." Water resources research 33(1): 177-185.

17. Le Ngo, L., et al. (2007). "Simulation and optimisation modelling approach for operation of the Hoa Binh reservoir, Vietnam." Journal of hydrology 336(3): 269-281.

18. Leliavsky, S. (1957). "Irrigation and hydraulic design." volume two "Irrigation work" Chapman and Hall, London, England.

19. MUTTIL, N. and S.-Y. Liong (2004). "Superior exploration-exploitation balance in shuffled complex evolution." Journal of hydraulic engineering 130(12): 1202-1205.

20. Singh, R. M. (2011). "Design of barrages with genetic algorithm based embedded simulation optimization approach." Water resources management 25(2): 409-429.

21. Singh, R. M. (2011). Optimal hydraulic structures profiles under uncertain seepage head. World Renewable Energy Congress-Sweden; 8-13 May; 2011; Linköping; Sweden, Linköping University Electronic Press.

22. Thyer, M., et al. (1999). "Probabilistic optimization for conceptual rainfall-runoff models: A comparison of the shuffled complex evolution and simulated annealing algorithms." Water resources research 35(3): 767-773.

23. Wu, J. and X. Zhu (2006). Using the shuffled complex evolution global optimization method to solve groundwater management models. Asia-Pacific Web Conference, Springer.

24. Wu, J., et al. (1999). "Using genetic algorithm based simulated annealing penalty function to solve groundwater management model." Science in China Series E: Technological Sciences 42(5): 521-529. 